\title{
Syntheses of Biliverdin Derivatives Sterically Locked at the CD-Ring Components
}

\author{
Mostafa A. S. Hammam, Hiroshi Nakamura, Yukari Hirata, Htoi Khawn, \\ Yasue Murata, Hideki Kinoshita, and Katsuhiko Inomata*
}

Division of Material Sciences, Graduate School of Natural Science and Technology, Kanazawa University, Kakuma, Kanazawa 920-1192

Received March 22, 2006; E-mail: inomata@ cacheibm.s.kanazawa-u.ac.jp

Total syntheses of biliverdin derivatives with a Z-syn, Z-anti, or E-syn CD-ring components were accomplished via new and efficient methods for the construction of sterically locked CD-ring components towards the elucidation of the stereochemistry of the chromophore in phytochromes.

Light is vital for photosynthesis, and it is also necessary for directing plant growth and development. The sensing of light in environmental conditions is essential for plants as vision is for animals. To fine-tune their development according to light intensity, direction, wavelength, and periodicity, they possess multiple light sensors. There are several light-sensing systems involved in these responses, such as the blue light sensitive system with cryptochrome ${ }^{1 \mathrm{a}}$ or phototropin $^{1 \mathrm{~b}}$ and the red light sensitive system with phytochrome. ${ }^{\text {lc }}$ Phytochromes are chromoproteins that have either phytochromobilin $(\mathrm{P} \Phi \mathrm{B})$ or phytocyanobilin (PCB) as a chromophore, which is covalently bound to the protein by a thioether bond through an A-ring ethylidene side chain and responds to red and far-red light through a reversible interchange between $Z$ - and $E$-forms at the $\mathrm{C} 15$ position of the chromophores (Fig. 1). ${ }^{2}$ This double-bond photoisomerization converts the physiologically inactive red light absorbing $\mathrm{P}_{\mathrm{r}}$ form into the active far-red light absorbing $\mathrm{P}_{\mathrm{fr}}$ form and vice versa. The interchange between the $\mathrm{P}_{\mathrm{r}}$ and $\mathrm{P}_{\mathrm{fr}}$ forms is essential for light absorbing biological processes in the phytochrome chromophore function. Some bacterial phytochromes have biliverdin (BV) as a natural chromophore, and we have recently determined that BV covalently binds to the apoprotein of Agrobacterium phytochrome Agp1 via its A-ring vinyl side chain. ${ }^{3}$

During photoconversion, the chromophore also moves around the exocyclic single bonds. In principle, each single bond can adopt either a syn or anti conformation. ${ }^{4}$ Vibrational spectroscopy provided indirect insight into the conformation of
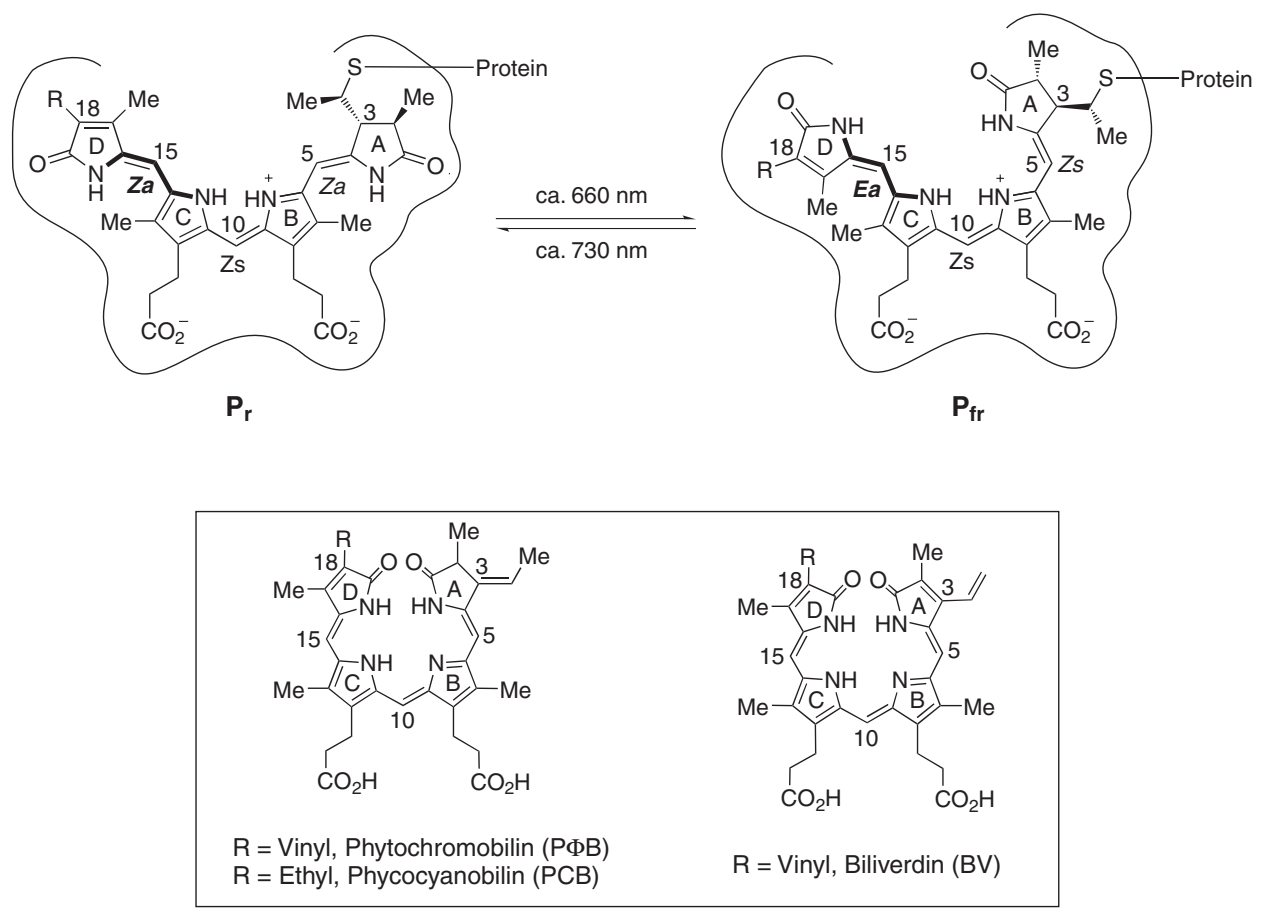

Fig. 1. Photoreversibility of phytochromes between $\mathrm{P}_{\mathrm{r}}$ and $\mathrm{P}_{\mathrm{fr}}$, and the structure of phytochrome chromophores. 
the phytochrome chromophore in the $\mathrm{P}_{\mathrm{r}}, \mathrm{P}_{\mathrm{fr}}$, and intermediate states, but the data were ambiguous and have been interpreted in different ways. ${ }^{2,5-7}$ For example, it was proposed that the formation of $\mathrm{P}_{\mathrm{fr}}$ is accompanied by a syn/anti rotation around the $\mathrm{C} 14-\mathrm{C} 15$ single bond. ${ }^{5}$ More recently, interpretation of resonance Raman spectra by density functional theory calculations proposed that the $\mathrm{C} 14-\mathrm{C} 15$ single bond is in anti conformation throughout the entire photocycle and that the C5-C6 single bond rotates from anti to syn upon conversion from $\mathrm{P}_{\mathrm{r}}$ to $\mathrm{P}_{\mathrm{fr}}$ as shown in Fig. 1. ${ }^{2}$

To analyze the structure and function of the chromophore in phytochromes, we have studied on the total syntheses of natural and unnatural chromophores. ${ }^{8-11}$ In this paper, we describe the syntheses of three different types of $\mathrm{BV}$ derivatives, in which the stereochemistry between the rings $\mathrm{C}$ and $\mathrm{D}$ are locked in Z-syn, Z-anti, and E-syn configuration and conformation, ${ }^{12}$ respectively, to determine the stereochemistry of the chromophore at the $\mathrm{C} 15$ position of $\mathrm{P}_{\mathrm{r}}$ and $\mathrm{P}_{\mathrm{fr}}$ forms and the function of the reconstituted Agp1. The retro-synthetic analyses of the three chromophores are shown in Fig. 2.

\section{Results and Discussion}

Preparation of Allyl (Z)-3-(4-Methyl-5-\{[4-methyl-5-oxo3-vinyl-1H-pyrrol-2(5H)-ylidene]methyl $\}-1 H$-pyrrol-3-yl)propanoate (4). The AB-ring component $\mathbf{4}$ is common for all chromophores prepared herein. We previously reported that it can be readily prepared by cleavage of BV diallyl ester with thiobarbituric acid in methanol; however, unusable barbituric acid adducts were produced at the same time. ${ }^{13 \mathrm{c}}$ Therefore, an alternative method was developed starting from 3-methyl4-[2-( $p$-tolylthio)ethyl]-5-tosyl-1,5-dihydro-2H-pyrrol-2-one ${ }^{8 \mathrm{f}}$ (11) as the A-ring precursor and $t$-butyl 3-(3-allyloxy-3-oxopropyl)-5-formyl-4-methyl-1H-pyrrole-2-carboxylate ${ }^{8 c}$ (10a), the latter of which is a precursor common to the $\mathrm{B}$ - and C-rings of BV, as shown in Scheme 1. Compounds 11 and 10a were coupled according to the original Wittig-type coupling reac$\operatorname{tion}^{8 \mathrm{~b}}$ in which tributylphosphine and 1,8-diazabicyclo[5.4.0]-
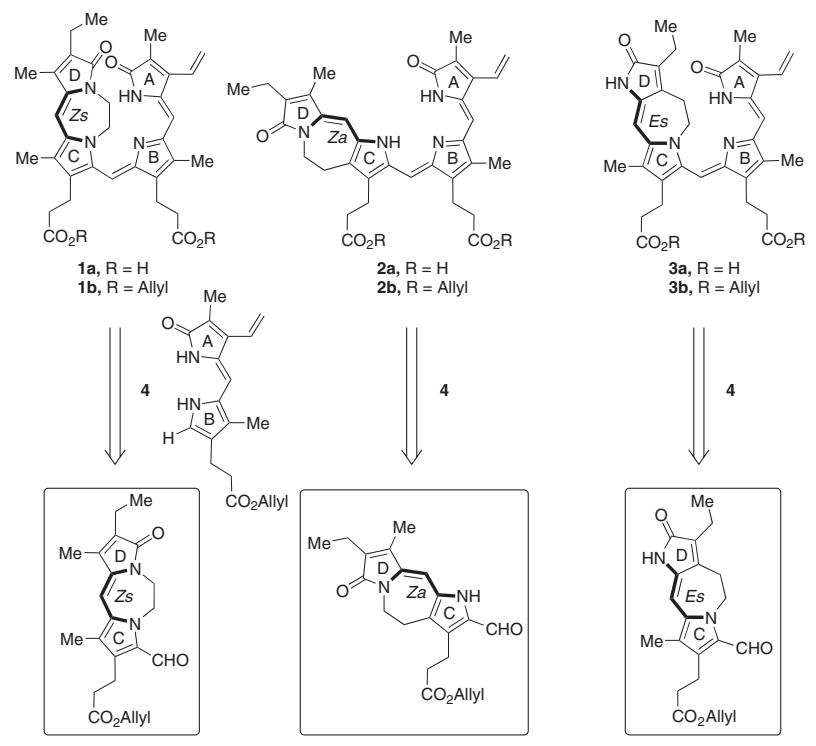

$$
\text { Base } \sum_{\mathrm{Br}}^{\mathrm{Br}} \bigvee\left(\mathrm{R}^{1}, \mathrm{R}^{2}=\mathrm{Me}\right) \text { Base } / /\left(\begin{array}{l}
\mathrm{R}^{1}=\mathrm{Me} \\
\mathrm{R}^{2}=\mathrm{CH}_{2} \mathrm{CH}_{2} \mathrm{Cl}
\end{array}\right)
$$

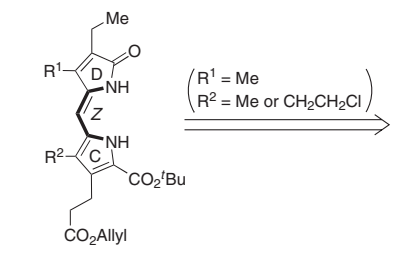

$(Z)-8 \mathrm{a}, \mathrm{R}^{1}=\mathrm{R}^{2}=\mathrm{Me}$

$(Z)-8 \mathbf{b}, \mathrm{R}^{1}=\mathrm{Me}, \mathrm{R}^{2}=\mathrm{CH}_{2} \mathrm{CH}_{2} \mathrm{Cl}$
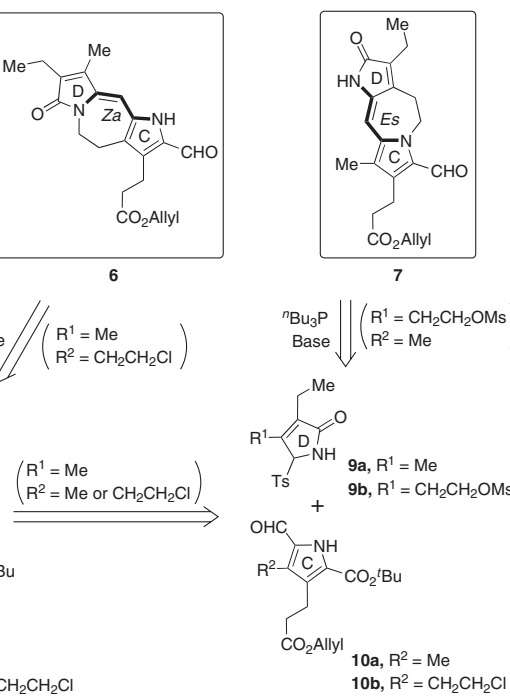

Fig. 2. Retrosynthetic analysis of the sterically locked chromophores 1-3.

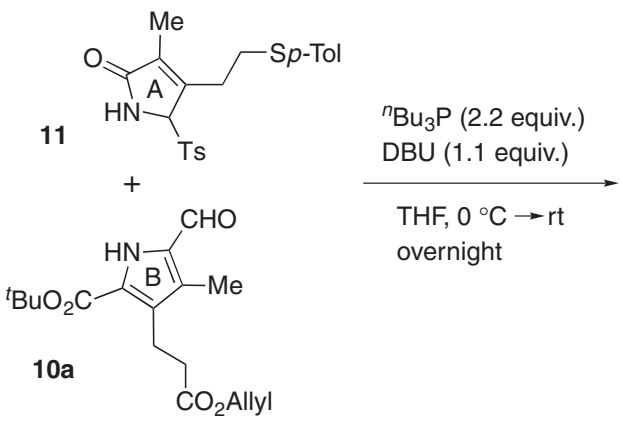

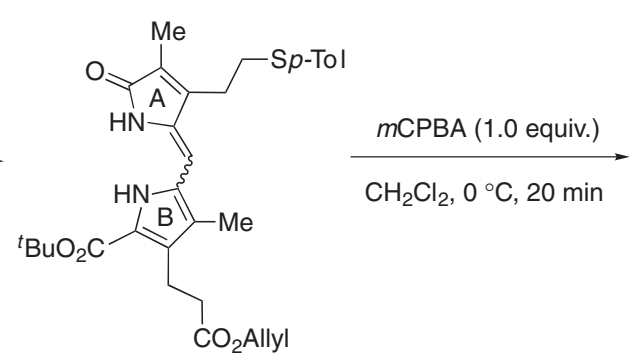

$12,88 \%$

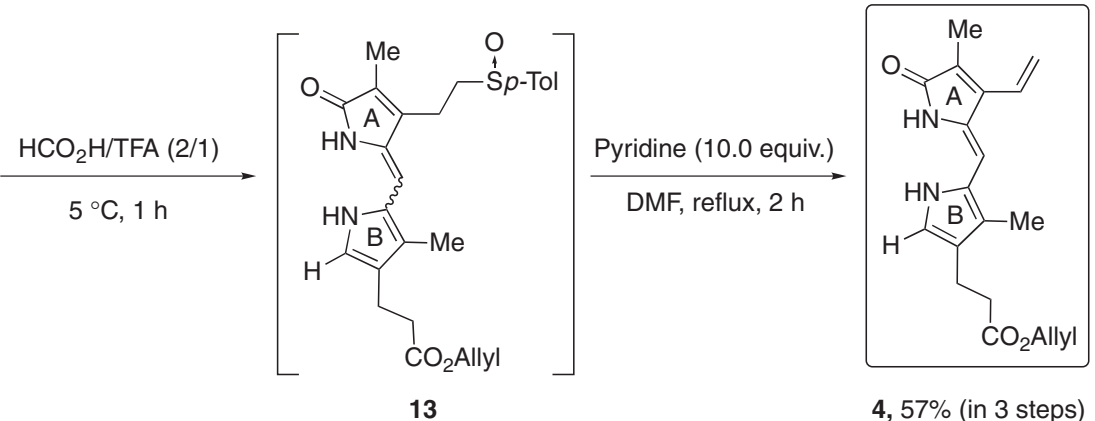

Scheme 1 


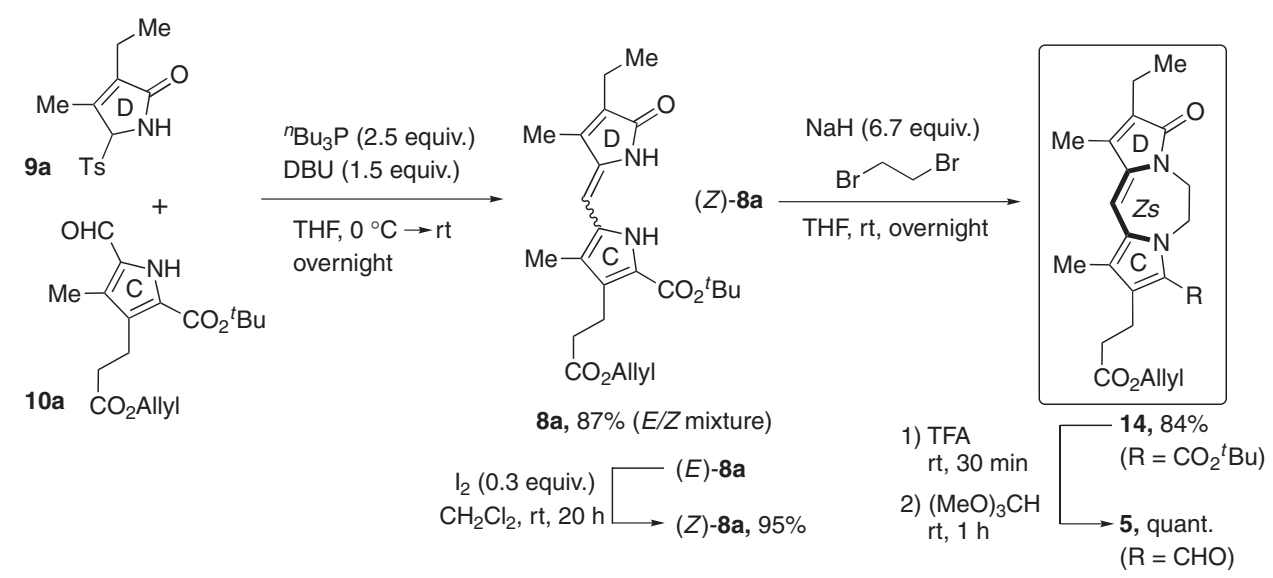

Scheme 2.

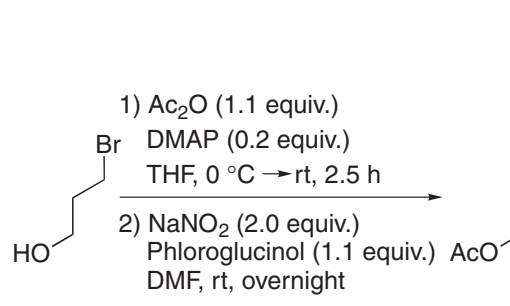

15

\section{$16,53 \%$} (in two steps)

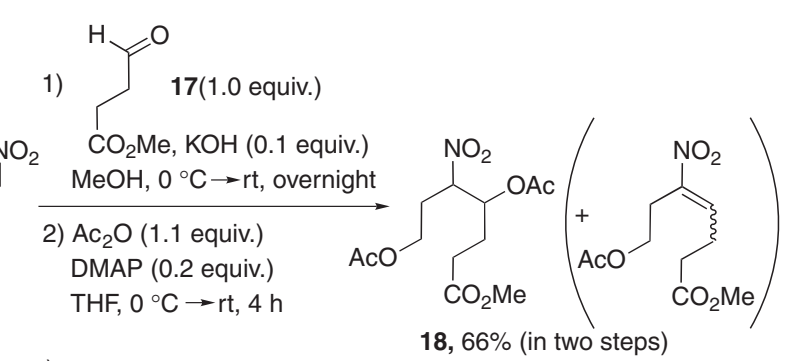

$18,66 \%$ (in two steps)

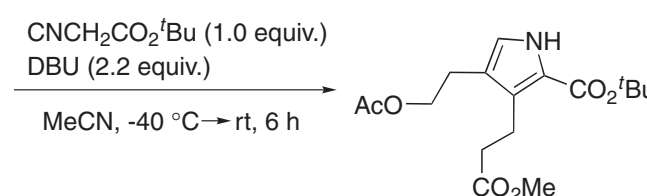

$19,55 \%$

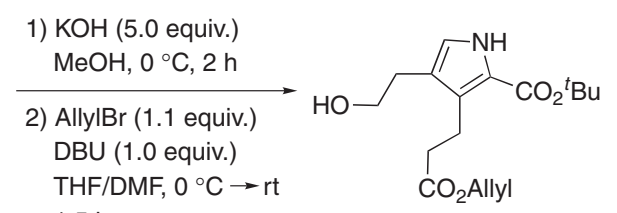

20, $60 \%$ (in two steps)<smiles>CC(C)(C)OC(=O)c1[nH]c(C=O)c(CCCl)c1CCC(=O)O[Mg]</smiles>

10b, $94 \%$

Scheme 3.

undec-7-ene (DBU) are used in THF to afford a mixture of $Z$ and $E$-isomers of the AB-ring precursor 12 bearing a $p$-tolylthioethyl side chain in $88 \%$ yield. Compound $\mathbf{1 2}$ was converted to the corresponding sulfoxide with $m \mathrm{CPBA}$ in $\mathrm{CH}_{2} \mathrm{Cl}_{2}$, followed by treatment with a mixture of formic acid and trifluoroacetic acid (TFA) at $5{ }^{\circ} \mathrm{C}$ to afford the decarboxylated dipyrrin-1(10H)-one intermediate $\mathbf{1 3}$. The crude product $\mathbf{1 3}$ was refluxed in DMF in the presence of pyridine to afford the desired AB-ring component $\mathbf{4}$ as only Z-isomer in $57 \%$ yield in three steps from compound $\mathbf{1 2}$.

Preparation of Allyl (Z)-3-(2-Ethyl-8-formyl-1,10-dimethyl-3-oxo-5,6-dihydro-3H-dipyrrolo[1,2- $\left.d: 2^{\prime}, 1^{\prime}-g\right][1,4]-$ diazepin-9-yl)propanoate (5). The sterically locked CD-ring component $\mathbf{5}$ bearing Z-syn configuration and conformation was prepared via our Wittig-type coupling reaction between 3-ethyl-4-methyl-5-tosyl-1,5-dihydro-2H-pyrrol-2-one ${ }^{8 b} \quad$ (9a) and formylpyrrole 10a in the presence of a mixture of tributyl- phosphine and DBU in THF to afford a mixture of coupling products $(Z)$ - and $(E)-\mathbf{8 a}$ in $87 \%$ yield (Scheme 2 ). The coupling product $(E)$-8a was readily converted to the corresponding isomer $(Z)$-8a by treatment with a catalytic amount of iodine in $\mathrm{CH}_{2} \mathrm{Cl}_{2}$ in $95 \%$ yield. Compound (Z)-8a, thus obtained, was then reacted with 1,2-dibromoethane in the presence of $\mathrm{NaH}$ in THF to afford the cyclized CD-ring component $\mathbf{1 4}$ in $84 \%$ yield. The $t$-butoxycarbonyl group of compound $\mathbf{1 4}$ was converted to a formyl group by treating with TFA followed by addition of trimethyl orthoformate $(\mathrm{MeO})_{3} \mathrm{CH}$ at room temperature to give the formylated $\mathrm{CD}$-ring component 5 in quantitative yield.

Preparation of $t$-Butyl 3-(3-Allyloxy-3-oxopropyl)-4(2-chloroethyl)-5-formyl-1H-pyrrole-2-carboxylate (10b). The formylpyrrole derivative ${ }^{11} \mathbf{1 0 b}$ was prepared starting from the commercially available 3-bromo-1-propanol (15) as shown in Scheme 3. Alcohol $\mathbf{1 5}$ was first acetylated using acetic 


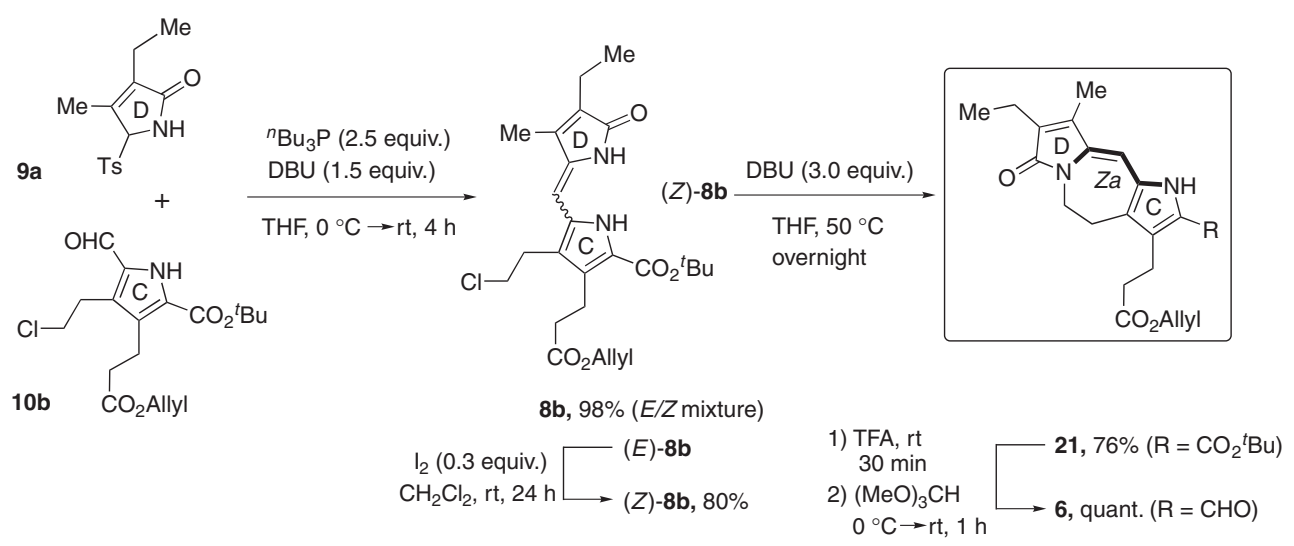

Scheme 4.
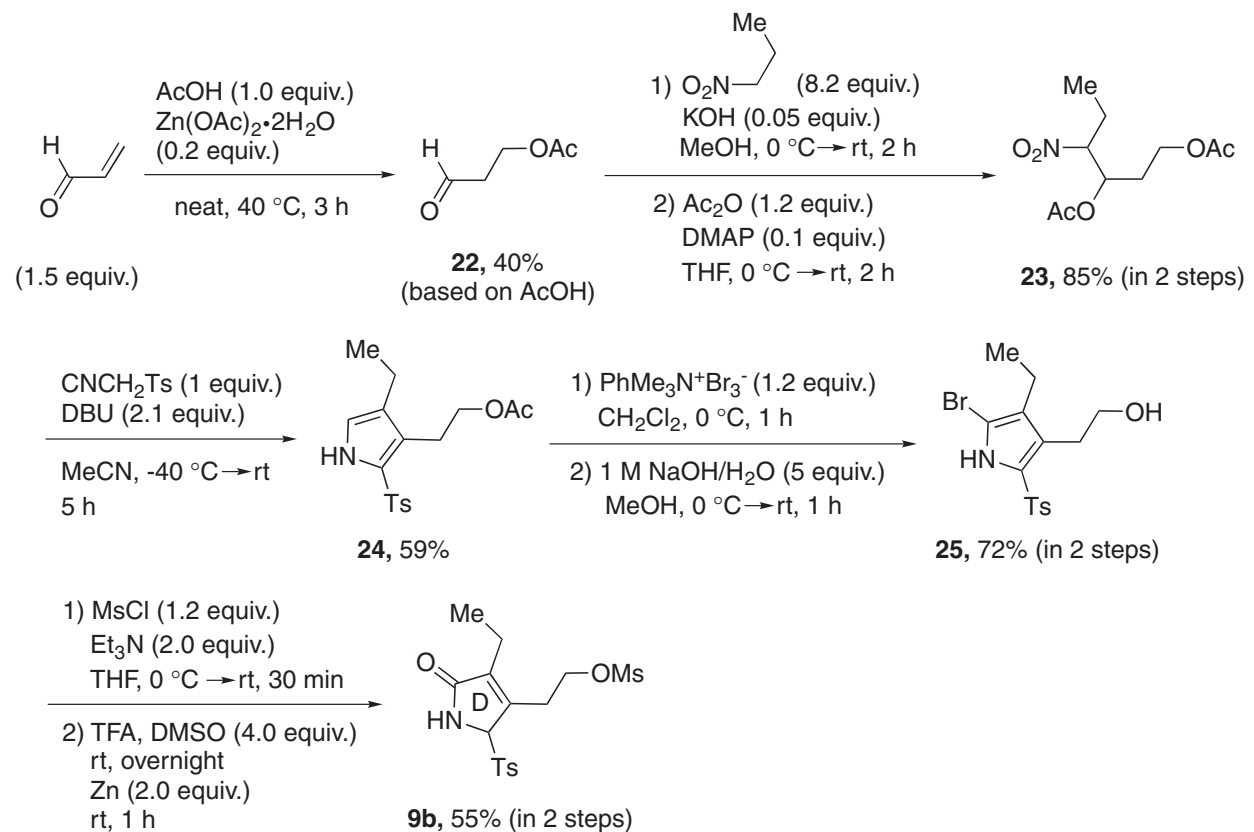

Scheme 5 .

anhydride in the presence of catalytic amount of 4-(dimethylamino)pyridine (DMAP) in THF, followed by nitration with sodium nitrite in the presence of phloroglucinol in DMF to give 3-nitropropyl acetate (16) in 53\% yield in two steps. Compound 16 was coupled with the oxo-ester 17 in a manner similar to our previous preparation of the B- and C-rings, ${ }^{8 c, g}$ followed by acetylation of the resulting nitro-alcohol to give the nitro-acetate $\mathbf{1 8}$ which was contaminated with the corresponding nitro-olefin. When compound $\mathbf{1 8}$ was treated with $t$-butyl isocyanoacetate and DBU according to Barton's meth$\mathrm{od}^{14}$ in acetonitrile, the pyrrole derivative 19 was obtained in 55\% yield. Hydrolysis of compound 19 with $\mathrm{KOH}$ in $\mathrm{MeOH}$, followed by allylation with allyl bromide in the presence of $\mathrm{DBU}$ in THF/DMF afforded the pyrrole $\mathbf{2 0}$ in $60 \%$ yield. When compound $\mathbf{2 0}$ was formylated by Vilsmeier reaction to give the formylated product in situ, chlorination of the hydroxy group proceeded simultaneously to afford the formylpyrrole 10b bearing 2-chloroethyl group in $94 \%$ yield.

Preparation of Allyl (Z)-3-(8-Ethyl-2-formyl-9-methyl-7oxo-1,4,5,7-tetrahydrodipyrrolo[1,2- $\left.a: 2^{\prime}, 3^{\prime}-d\right]$ azepin-3-yl)- propanoate (6). As shown in Scheme 4, compounds 9a and 10b were coupled according to the Wittig-type reaction developed in our laboratory using tributylphosphine in the presence of DBU in THF to afford the CD-ring precursor $\mathbf{8 b}$ as a mixture of $E$ - and $Z$-isomers in $98 \%$ yield. We found that compound $(E)$-8b should be converted to the $Z$-isomer by treating with a catalytic amount of iodine in $\mathrm{CH}_{2} \mathrm{Cl}_{2}$ prior to the cyclization. Compound (Z)-8b was cyclized at $50{ }^{\circ} \mathrm{C}$ in the presence of DBU in THF affording the desired product 21 in $76 \%$ yield. Subsequent formylation was accomplished by treating with $(\mathrm{MeO})_{3} \mathrm{CH}$ in TFA to give the formylated $\mathrm{CD}$ ring component $\mathbf{6}$ in quantitative yield.

Preparation of 3-Ethyl-4-[2-(mesyloxy)ethyl]-5-tosyl-1,5dihydro-2H-pyrrol-2-one (9b). The 5-tosylpyrrolinone derivative 9b was prepared starting from propenal as shown in Scheme 5. Treatment of propenal with acetic acid in the presence of catalytic amount of zinc diacetate afforded 3-oxopropyl acetate (22) in $40 \%$ yield. ${ }^{15}$ Compound 22 was then coupled with 1-nitropropane according to Henry reaction in the presence of catalytic amount of $\mathrm{KOH}$ in $\mathrm{MeOH}$. The resulting 


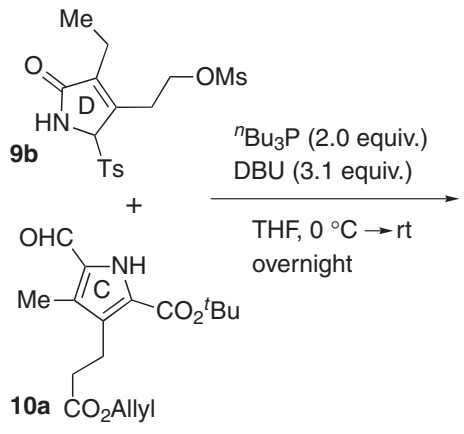

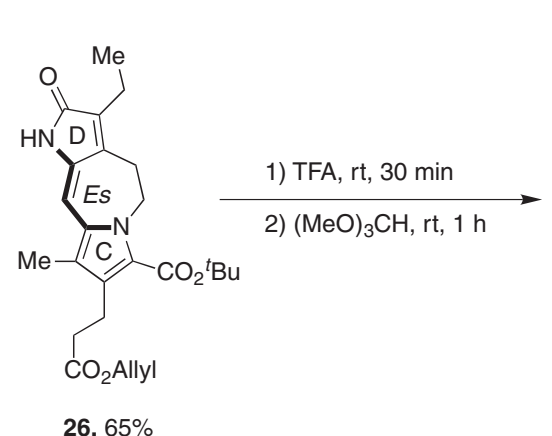

$26,65 \%$

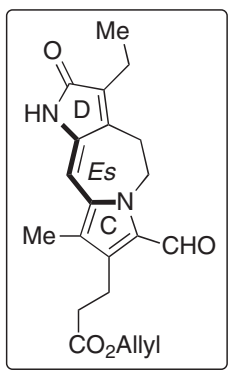

$7,85 \%$

Scheme 6 .

Table 1. Construction of the Biliverdin Derivatives with the Sterically Locked CD-Ring Components

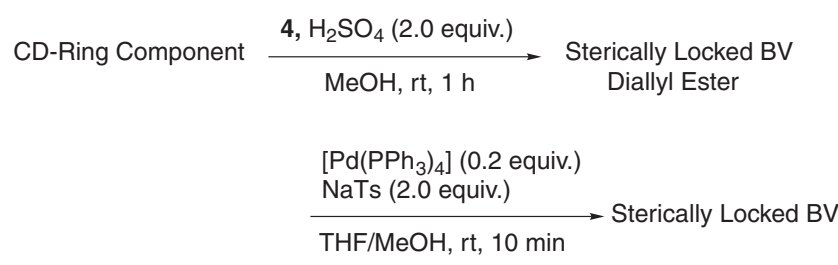

\begin{tabular}{ccc}
\hline $\begin{array}{c}\text { CD-ring } \\
\text { component }\end{array}$ & $\begin{array}{c}\text { Sterically locked } \\
\text { BV diallyl ester } / \%\end{array}$ & $\begin{array}{c}\text { Sterically locked } \\
\text { BV } / \%\end{array}$ \\
\hline $\mathbf{5}$ & $\mathbf{1 b}, 69$ & $\mathbf{1 a}, 80$ \\
$\mathbf{6}$ & $\mathbf{2 b}, 87$ & $\mathbf{2 a}, 90$ \\
$\mathbf{7}$ & $\mathbf{3 b}, 45$ & $\mathbf{3 a}, 42$ \\
\hline
\end{tabular}

nitro-alcohol was then acetylated using acetic anhydride in the presence of catalytic amount of DMAP in THF to give the nitro-diacetate $\mathbf{2 3}$ in $85 \%$ yield in two steps. Compound $\mathbf{2 3}$ was reacted under Barton's method conditions, i.e., tosylmeth$\mathrm{yl}$ isocyanide (TosMIC) in the presence of DBU, to afford tosylpyrrole derivative $\mathbf{2 4}$ in $59 \%$ yield. Compound $\mathbf{2 4}$ was then brominated with trimethylphenylammonium tribromide $\left(\mathrm{PhMe}_{3} \mathrm{~N}^{+} \mathrm{Br}_{3}{ }^{-}\right)$in $\mathrm{CH}_{2} \mathrm{Cl}_{2}$, followed by hydrolysis of the acetoxy group with $1 \mathrm{M}\left(=1 \mathrm{~mol} \mathrm{dm}^{-1}\right)$ aq $\mathrm{NaOH}$ in $\mathrm{MeOH}$ to give compound $\mathbf{2 5}$ in $\mathbf{7 2 \%}$ yield in two steps. Mesylation and subsequent redox-type reaction ${ }^{8 \mathrm{a}, \mathrm{i}}$ using DMSO and zinc in TFA afforded the 5-tosylpyrrolinone derivative $\mathbf{9 b}$ in $55 \%$ yield in two steps.

Preparation of Allyl (E)-3-(3-Ethyl-7-formyl-9-methyl-2oxo-1,2,4,5-tetrahydrodipyrrolo[1,2- $\left.a: 2^{\prime}, 3^{\prime}-d\right]$ azepin-8-yl)propanoate (7). As shown in Scheme 6, compounds 9b and 10a were coupled by a Wittig-type reaction with tributylphosphine in the presence of DBU in THF to afford directly the cyclized CD-ring component $\mathbf{2 6}$ as E-syn isomer in 65\% yield. Formylation reaction was carried out by treating with TFA and subsequent addition of $(\mathrm{MeO})_{3} \mathrm{CH}$ to give the formylated $\mathrm{CD}$ ring component 7 in $85 \%$ yield.

Construction of the Biliverdin Derivatives as 15Z-syn, 15Z-anti, and 15E-syn Chromophores in Free Acid Forms. Coupling reactions between the CD-ring components 5, 6, and $\mathbf{7}$, prepared above, with the AB-ring component 4 were carried out in methanol under acidic conditions to afford the sterically locked BV diallyl ester derivatives $\mathbf{1 b}, \mathbf{2 b}$, and $\mathbf{3 b}$ in 69,87 , and $45 \%$ yields, respectively (Table 1 ).

Finally, the carboxylate groups were deprotected via a $\mathrm{Pd}^{0}$ - catalyzed reaction using sodium $p$-toluenesulfinate (NaTs) as a nucleophile in $\mathrm{THF} / \mathrm{MeOH}$ to give the desired chromophores 1a, 2a, and 3a in 80, 90, and $42 \%$ yields, respectively, in free acid forms.

Chromophores 1a, 2a, and 3a were attached to the Agp1 apoprotein to determine the stereochemistry of CD-ring component of BV in Agp1. It was found that compound $\mathbf{2 a}$, which is a BV derivative having $15 \mathrm{Za}$ configuration and conformation, forms a covalent bond with Agp1 apoprotein, and the absorption spectrum corresponding to $\mathrm{P}_{\mathrm{r}}$ form was observed. Furthermore, size exclusion chromatograph of Agp1-M15 (the $N$-terminal 504 amino acids of Agp1) apoprotein adduct with compound 2a and the autophosphorylation of the Agp1 adduct with compound 2a showed that the stereochemistry of CD-ring moiety of $\mathrm{P}_{\mathrm{r}}$ form of natural Agp1 is $15 \mathrm{Za} .{ }^{16}$ Recently, we also prepared another derivative of the chromophore in which the stereochemistry of the CD-ring moiety is fixed to $15 E a .{ }^{17}$ This $15 E a$ chromophore was also attached to the Agp1 apoprotein, and the adduct was found to be the $\mathrm{P}_{\mathrm{fr}}$ form of Agp $1 .{ }^{16}$ From these results, sterically locked chromophores will open new avenues of investigation concerning the stereochemistry and function of phytochrome chromophores both in vitro and in vivo.

\section{Experimental}

${ }^{1}$ HNMR spectra were recorded on JEOL JNM-GX Lambda 400 and 300 NMR spectrometers. Chemical shifts are reported in $\delta$-scale relative to TMS $(\delta=0)$ as an internal standard. The IR spectra were measured on a JASCO FT/IR-230 spectrometer, and the MS spectra were recorded by using Hitachi M-80 and JEOL SX-102A mass spectrometers. All solvents were distilled and stored over drying agents. THF was freshly distilled from sodium diphenylketyl. Thin-layer chromatography (TLC) and flash column chromatography were performed using Merck's silica gel $60 \mathrm{PF}_{254}$ (Art. 7749) and Cica-Merck's silica gel 60 (No. 9385-5B), respectively. Commercially available reagents were used without further purification, unless otherwise noted.

$t$-Butyl 3-(3-Allyloxy-3-oxopropyl)-4-methyl-5-(\{4-methyl-5oxo-3-[2-(p-tolylthio)ethyl]-1H-pyrrol-2(5H)-ylidene\}methyl)$1 \mathrm{H}$-pyrrole-2-carboxylate (12). To a mixed solution of 5-tosylpyrrolinone $^{8 \mathrm{e}} \mathbf{1 1}(2.0 \mathrm{~g}, 5 \mathrm{mmol})$ and formylpyrrole ${ }^{8 \mathrm{~b}} \mathbf{1 0 a}(1.6 \mathrm{~g}$, $5 \mathrm{mmol})$ in THF $(30 \mathrm{~mL})$ was added ${ }^{n} \mathrm{Bu}_{3} \mathrm{P}(2.7 \mathrm{~mL}, 11 \mathrm{mmol})$ dropwise at $0{ }^{\circ} \mathrm{C}$ under $\mathrm{N}_{2}$, followed by dropwise addition of DBU $(0.82 \mathrm{~g}, 5.5 \mathrm{mmol})$ in THF $(2 \mathrm{~mL})$. The reaction mixture was allowed to stir at room temperature overnight. The solvent was removed under reduced pressure, and the residue was partitioned between EtOAc and water. The organic layer was washed with both a saturated aqueous solution of $\mathrm{NH}_{4} \mathrm{Cl}$ and brine, and 
then dried over $\mathrm{MgSO}_{4}$. The solvent was evaporated, and the product was separated by flash column chromatography $\left(\mathrm{SiO}_{2}\right.$, hexane $/$ EtOAc $=4 / 1, \mathrm{v} / \mathrm{v})$ to give compound $12(2.42 \mathrm{~g}, 88 \%)$ as a yellow solid of the mixture of $(Z)-(60 \%)$ and $(E)$-isomers (28\%). Mp 177.5-178.0 ${ }^{\circ} \mathrm{C}$ (from EtOAc/hexane). IR (KBr) 3330, 3122, 2974, 1735, 1695, 1656, 1450, 1365, 1273, 1157, 1132, 987, 847, 810, $760 \mathrm{~cm}^{-1} ;{ }^{1} \mathrm{HNMR}\left(\mathrm{CDCl}_{3}, 300 \mathrm{MHz}\right)(Z)$-isomer: $\delta$ $1.56(\mathrm{~s}, 9 \mathrm{H}), 1.93(\mathrm{~s}, 3 \mathrm{H}), 2.00(\mathrm{~s}, 3 \mathrm{H}), 2.34(\mathrm{~s}, 3 \mathrm{H}), 2.54$ (t, $J=$ $8.1 \mathrm{~Hz}, 2 \mathrm{H}), 2.79(\mathrm{t}, J=7.9 \mathrm{~Hz}, 2 \mathrm{H}), 2.82(\mathrm{t}, J=8.3 \mathrm{~Hz}, 2 \mathrm{H})$, $3.08(\mathrm{t}, J=8.3 \mathrm{~Hz}, 2 \mathrm{H}), 4.59(\mathrm{~d}, J=5.7 \mathrm{~Hz}, 2 \mathrm{H}), 5.23(\mathrm{dd}, J=$ $10.4,1.3 \mathrm{~Hz}, 1 \mathrm{H}), 5.31(\mathrm{dd}, J=17.2,1.3 \mathrm{~Hz}, 1 \mathrm{H}), 5.79(\mathrm{~s}, 1 \mathrm{H})$, 5.92 (ddt, $J=17.2,10.4,5.7 \mathrm{~Hz}, 1 \mathrm{H}), 7.13(\mathrm{~d}, J=8.1 \mathrm{~Hz}, 2 \mathrm{H})$, 7.32 (d, $J=8.1 \mathrm{~Hz}, 2 \mathrm{H}), 9.48$ (brs, $1 \mathrm{H}), 9.52$ (brs, $1 \mathrm{H}) ;(E)$-isomer: $\delta 1.57(\mathrm{~s}, 9 \mathrm{H}), 1.82(\mathrm{~s}, 3 \mathrm{H}), 1.96(\mathrm{~s}, 3 \mathrm{H}), 2.29(\mathrm{~s}, 3 \mathrm{H}), 2.55$ (t, $J=8.0 \mathrm{~Hz}, 2 \mathrm{H}), 2.55-2.65(\mathrm{~m}, 4 \mathrm{H}), 3.00(\mathrm{t}, J=8.0 \mathrm{~Hz}, 2 \mathrm{H})$, $4.59(\mathrm{~d}, J=5.7 \mathrm{~Hz}, 2 \mathrm{H}), 5.23(\mathrm{~d}, J=10.5 \mathrm{~Hz}, 1 \mathrm{H}), 5.31(\mathrm{dd}, J=$ $17.2,1.3 \mathrm{~Hz}, 1 \mathrm{H}$ ), 5.92 (ddt, $J=17.2,10.4,5.7 \mathrm{~Hz}, 1 \mathrm{H}$ ), 6.11 (s, $1 \mathrm{H}), 7.03(\mathrm{~d}, J=8.2 \mathrm{~Hz}, 2 \mathrm{H}), 7.09(\mathrm{~d}, J=8.2 \mathrm{~Hz}, 2 \mathrm{H}), 8.20$ (brs, $1 \mathrm{H}), 8.98$ (brs, $1 \mathrm{H}$ ). Found: C, 67.62; H, 6.93; N, 4.82\%. Calcd for $\mathrm{C}_{31} \mathrm{H}_{38} \mathrm{~N}_{2} \mathrm{O}_{5} \mathrm{~S}: \mathrm{C}, 67.61 ; \mathrm{H}, 6.95 ; \mathrm{N}, 5.09 \%$.

Allyl (Z)-3-\{4-Methyl-5-[(4-methyl-5-oxo-3-vinyl-1H-pyrrol-2(5H)-ylidene)methyl]-1H-pyrrol-3-yl\}propanoate (4). To a solution of compound $\mathbf{1 2}(2.42 \mathrm{~g}, 4.4 \mathrm{mmol})$ in $\mathrm{CH}_{2} \mathrm{Cl}_{2}(20 \mathrm{~mL})$, a solution of $m \mathrm{CPBA}$ (70\% purity, $1.085 \mathrm{~g}, 4.4 \mathrm{mmol}$ ) in $\mathrm{CH}_{2} \mathrm{Cl}_{2}$ $(5 \mathrm{~mL})$ was added dropwise at $0{ }^{\circ} \mathrm{C}$, and the mixture was allowed to stir for $20 \mathrm{~min}$. The reaction mixture was quenched by the addition of a saturated aqueous solution of $\mathrm{NaHSO}_{3}$, and then, the organic solvent was removed under reduced pressure. The residue was partitioned between EtOAc and water. The organic layer was washed with a saturated aqueous solution of $\mathrm{NaHCO}_{3}$ and with brine, and dried over $\mathrm{MgSO}_{4}$. The solvent was evaporated, and the solid residue was dissolved in a mixture of formic acid and TFA $(2 / 1, \mathrm{v} / \mathrm{v}, 9 \mathrm{~mL} / \mathrm{mmol})$ and allowed to stir at $5{ }^{\circ} \mathrm{C}$ for $1 \mathrm{~h}$. The reaction mixture was treated with solid $\mathrm{Na}_{2} \mathrm{CO}_{3}$ and was partitioned between EtOAc and water. The organic layer was washed with a saturated aqueous solution of $\mathrm{NaHCO}_{3}$ and brine, and dried over $\mathrm{Na}_{2} \mathrm{SO}_{4}$. The solvent was evaporated, and the residual mixture was dissolved in DMF $(20 \mathrm{~mL})$ under $\mathrm{N}_{2}$. After addition of pyridine $(3 \mathrm{~mL}, 44 \mathrm{mmol})$, the mixture was refluxed for $2 \mathrm{~h}$ with stirring. The reaction mixture was partitioned between EtOAc/ $\mathrm{Et}_{2} \mathrm{O}$ and water, and the organic layer was successively washed with $1 \mathrm{M} \mathrm{HCl}$, a saturated aqueous solution of $\mathrm{NaHCO}_{3}$ and brine, and then dried over $\mathrm{MgSO}_{4}$. The solvent was evaporated, and the residue was separated by flash column chromatography $\left(\mathrm{SiO}_{2}\right.$, hexane $/$ EtOAc $=3 / 1, \mathrm{v} / \mathrm{v}$ ) to afford compound $\mathbf{4}$ as a yellow solid $(850 \mathrm{mg})$ in $57 \%$ yield in three steps. Mp $151-153^{\circ} \mathrm{C}$ (from EtOAc/hexane). IR (KBr) 3336, 3154, 2920, 1738, 1657, 1638, $1442,1418,1377,1339,1262,1171,984,926,808,756 \mathrm{~cm}^{-1}$; ${ }^{1} \mathrm{H} \mathrm{NMR}\left(\mathrm{CDCl}_{3}, 400 \mathrm{MHz}\right) \delta 1.95(\mathrm{~s}, 3 \mathrm{H}), 2.09(\mathrm{~s}, 3 \mathrm{H}), 2.59(\mathrm{t}$, $J=7.7 \mathrm{~Hz}, 2 \mathrm{H}), 2.76(\mathrm{t}, J=7.6 \mathrm{~Hz}, 2 \mathrm{H}), 4.60,(\mathrm{~d}, J=5.6 \mathrm{~Hz}$, $2 \mathrm{H}), 5.23(\mathrm{~d}, J=10.5 \mathrm{~Hz}, 1 \mathrm{H}), 5.31(\mathrm{~d}, J=17.1 \mathrm{~Hz}, 1 \mathrm{H}), 5.56(\mathrm{~d}$, $J=17.5 \mathrm{~Hz}, 1 \mathrm{H}), 5.58(\mathrm{~d}, J=11.5 \mathrm{~Hz}, 1 \mathrm{H}), 5.92(\mathrm{ddt}, J=17.1$, $10.5,5.6 \mathrm{~Hz}, 1 \mathrm{H}), 6.18(\mathrm{~s}, 1 \mathrm{H}), 6.59(\mathrm{dd}, J=17.6,11.7 \mathrm{~Hz}, 1 \mathrm{H})$, 6.77 (brd, $J=1.7 \mathrm{~Hz}, 1 \mathrm{H}), 10.53(\mathrm{~s}, 1 \mathrm{H}), 11.34$ (s, 1H). Found: C, $69.90 ; \mathrm{H}, 6.71 ; \mathrm{N}, 8.56 \%$. Calcd for $\mathrm{C}_{19} \mathrm{H}_{22} \mathrm{~N}_{2} \mathrm{O}_{3}$ : C, 69.92; $\mathrm{H}$, $6.79 ; \mathrm{N}, 8.58 \%$

t-Butyl 3-(3-Allyloxy-3-oxopropyl)-5-[(4-ethyl-3-methyl-5oxo-1 $H$-pyrrol-2(5H)-ylidene)methyl]-4-methyl-1 $H$-pyrrole-2carboxylate (8a). To a mixed solution of 5-tosylpyrrolinone $9 \mathbf{a}^{8 \mathrm{~b}}$ $(313 \mathrm{mg}, 1.1 \mathrm{mmol})$ and formylpyrrole $\mathbf{1 0 a} \mathrm{a}^{8 \mathrm{a}}(300 \mathrm{mg}, 0.9 \mathrm{mmol})$ in THF $(18 \mathrm{~mL})$ was added ${ }^{n} \mathrm{Bu}_{3} \mathrm{P}(0.6 \mathrm{~mL}, 2.3 \mathrm{mmol})$ dropwise at $0{ }^{\circ} \mathrm{C}$ under $\mathrm{N}_{2}$, followed by dropwise addition of DBU $(213 \mathrm{mg}$,
$1.4 \mathrm{mmol})$ in THF $(2.0 \mathrm{~mL})$. The reaction mixture was allowed to stir at room temperature overnight. The solvent was removed under reduced pressure, and the residue was partitioned between EtOAc and water. The organic layer was washed with a saturated aqueous solution of $\mathrm{NH}_{4} \mathrm{Cl}$ and with brine, and dried over $\mathrm{MgSO}_{4}$. The solvent was evaporated, and the residue was separated by flash column chromatography $\left(\mathrm{SiO}_{2}\right.$, hexane $/$ EtOAc $\left.=4 / 1, \mathrm{v} / \mathrm{v}\right)$ to afford compound $\mathbf{8 a}(349 \mathrm{mg}, 87 \%)$ as a yellow solid [a mixture of $(Z)-(27 \%)$ and $(E)$-isomers $(60 \%)]$. IR $(\mathrm{KBr}) 3329,3130,2969$, 2927, 2871, 1739, 1696, 1657, 1453, 1368, 1275, 1265, 1136, 779, $720 \mathrm{~cm}^{-1}$. The $(Z)$ - and $(E)$-isomers were further separated by repeating the flash column chromatography with a longer column under the same conditions. ${ }^{1} \mathrm{HNMR}\left(\mathrm{CDCl}_{3}, 300 \mathrm{MHz}\right)(Z)-8 \mathrm{a}: \delta$ 1.09 (t, $J=7.5 \mathrm{~Hz}, 3 \mathrm{H}), 1.56(\mathrm{~s}, 9 \mathrm{H}), 2.08(\mathrm{~s}, 3 \mathrm{H}), 2.10(\mathrm{~s}, 3 \mathrm{H})$, $2.42(\mathrm{q}, J=7.4 \mathrm{~Hz}, 2 \mathrm{H}), 2.54(\mathrm{t}, J=8.1 \mathrm{~Hz}, 2 \mathrm{H}), 3.02(\mathrm{t}, J=8.1$ $\mathrm{Hz}, 2 \mathrm{H}), 4.59(\mathrm{~d}, J=5.9 \mathrm{~Hz}, 2 \mathrm{H}), 5.23(\mathrm{~d}, J=10.5 \mathrm{~Hz}, 1 \mathrm{H}), 5.30$ (d, $J=17.2 \mathrm{~Hz}, 1 \mathrm{H}), 5.91$ (ddt, $J=17.2,10.5,5.9 \mathrm{~Hz}, 1 \mathrm{H}), 5.93$ (s, 1H), $8.95(\mathrm{~s}, 1 \mathrm{H}), 9.40(\mathrm{~s}, 1 \mathrm{H}) ;(E)-8 \mathrm{a}: \delta 1.08(\mathrm{t}, J=7.5 \mathrm{~Hz}$, $3 \mathrm{H}), 1.56(\mathrm{~s}, 9 \mathrm{H}), 1.87(\mathrm{~s}, 3 \mathrm{H}), 1.99(\mathrm{~s}, 3 \mathrm{H}), 2.35(\mathrm{q}, J=7.5 \mathrm{~Hz}$, 2H), $2.56(\mathrm{t}, J=7.9 \mathrm{~Hz}, 2 \mathrm{H}), 3.02(\mathrm{t}, J=8.0 \mathrm{~Hz}, 2 \mathrm{H}), 4.58(\mathrm{~d}$, $J=5.7 \mathrm{~Hz}, 2 \mathrm{H}), 5.23(\mathrm{~d}, J=10.5 \mathrm{~Hz}, 1 \mathrm{H}), 5.31(\mathrm{~d}, J=17.2 \mathrm{~Hz}$, $1 \mathrm{H}), 5.91$ (ddt, $J=17.2,10.5,5.7 \mathrm{~Hz}, 1 \mathrm{H}), 6.17$ (s, 1H), 8.63 (s, $1 \mathrm{H}), 9.05(\mathrm{~s}, 1 \mathrm{H}) .(E)-8 \mathbf{a}(210 \mathrm{mg}, 0.5 \mathrm{mmol})$ was treated with a catalytic amount of iodine (41 mg, $0.16 \mathrm{mmol})$ in $\mathrm{CH}_{2} \mathrm{Cl}_{2}(10 \mathrm{~mL})$ for $20 \mathrm{~h}$ at room temperature. The solvent was evaporated, and the residue was partitioned between EtOAc and water. The organic layer was successively washed with a saturated aqueous solution of $\mathrm{NaHSO}_{3}$, a solution of $\mathrm{NaHCO}_{3}$, and brine, and then dried over $\mathrm{MgSO}_{4}$. The solvent was evaporated, and the residue was separated by flash column chromatography $\left(\mathrm{SO}_{2}\right.$, hexane/EtOAc $=4 / 1$, $\mathrm{v} / \mathrm{v})$ to give (Z)-8a $\left(200 \mathrm{mg}\right.$ ) in $95 \%$ yield. $\mathrm{Mp} 164-166^{\circ} \mathrm{C}$ (from EtOAc/hexane). Found: C, 67.16; H, 7.49; N, 6.48\%. Calcd for $\mathrm{C}_{24} \mathrm{H}_{32} \mathrm{~N}_{2} \mathrm{O}_{5}$ : C, 67.27; H, 7.53; N, 6.54\%.

t-Butyl (Z)-9-(3-Allyloxy-3-oxopropyl)-2-ethyl-1,10-dimethyl3-oxo-5,6-dihydro-3H-dipyrrolo[1,2- $d: 2^{\prime}, 1^{\prime}$-g] [1,4]diazepine-8carboxylate (14). To a suspension of $\mathrm{NaH}(34 \mathrm{mg}, 60 \%$ in mineral oil, $0.8 \mathrm{mmol})$ in THF $(1 \mathrm{~mL})$ was added a catalytic amount of 18-crown-6 (32 mg, $0.12 \mathrm{mmol})$, suspended in THF ( $1 \mathrm{~mL})$, and a solution of compound (Z)-8a (52 mg, $0.12 \mathrm{mmol})$ in THF $(2 \mathrm{~mL})$, followed by the addition of 1,2-dibromoethane $(3 \mathrm{~mL})$. The mixture was stirred at room temperature overnight. The solvent was removed under reduced pressure, and the residue was partitioned between EtOAc and water. The organic layer was washed with brine and dried over $\mathrm{MgSO}_{4}$. The solvent was evaporated, and the residue was purified by flash column chromatography $\left(\mathrm{SiO}_{2}\right.$, hexane $/$ EtOAc $=3 / 1, \mathrm{v} / \mathrm{v})$ to afford compound 14 (46 mg, 84\%) as a yellow solid. Mp $70-71{ }^{\circ} \mathrm{C}$ (from EtOAc/hexane). IR (neat) 2976, 2933, 1738, 1691, 1458, 1425, 1396, 1370, 1345, 1294, 1243, 1167, 1128, 1047, 1002, 959, 849, $773 \mathrm{~cm}^{-1}$; ${ }^{1} \mathrm{H}$ NMR $\left(\mathrm{CDCl}_{3}, 400 \mathrm{MHz}\right) \delta 1.12(\mathrm{t}, J=7.6 \mathrm{~Hz}, 3 \mathrm{H}), 1.58(\mathrm{~s}, 9 \mathrm{H}), 2.09$ (s, 3H), 2.13 (s, 3H), 2.39 (q, $J=7.6 \mathrm{~Hz}, 2 \mathrm{H}), 2.53(\mathrm{t}, J=8.1 \mathrm{~Hz}$, 2H), $3.00(\mathrm{t}, J=8.1 \mathrm{~Hz}, 2 \mathrm{H}), 4.59(\mathrm{~d}, J=5.9 \mathrm{~Hz}, 2 \mathrm{H}), 5.23(\mathrm{dd}$, $J=10.2,1.7 \mathrm{~Hz}, 1 \mathrm{H}), 5.30(\mathrm{dd}, J=17.3,1.7 \mathrm{~Hz}, 1 \mathrm{H}), 5.93$ (ddt, $J=17.3,10.2,5.9 \mathrm{~Hz}, 1 \mathrm{H}), 5.99(\mathrm{~s}, 1 \mathrm{H})$. The protons of the ethylene bridge were not observed clearly. Found: C, 68.58; H, 7.47; N, $6.08 \%$. Calcd for $\mathrm{C}_{26} \mathrm{H}_{34} \mathrm{~N}_{2} \mathrm{O}_{5}: \mathrm{C}, 68.70 ; \mathrm{H}, 7.54 ; \mathrm{N}, 6.16 \%$.

Allyl (Z)-3-(2-Ethyl-8-formyl-1,10-dimethyl-3-oxo-5,6-dihydro-3H-dipyrrolo[1,2-d:2',1'-g][1,4]diazepin-9-yl)propanoate (5). A solution of compound $\mathbf{1 4}(46 \mathrm{mg}, 0.1 \mathrm{mmol})$ in TFA $(1 \mathrm{~mL})$ was allowed to stir for $30 \mathrm{~min}$ at room temperature under $\mathrm{N}_{2}$. Then, $\left(\mathrm{CH}_{3} \mathrm{O}\right)_{3} \mathrm{CH}(0.5 \mathrm{~mL})$ was added dropwise. After stirring for $1 \mathrm{~h}$ at room temperature, the reaction mixture was 
quenched by adding water and extracted with EtOAc, and then, the organic layer was washed with a saturated aqueous solution of $\mathrm{NaHCO}_{3}$ and with brine, and dried over $\mathrm{MgSO}_{4}$. The solvent was evaporated, and the residue was separated by flash column chromatography $\left(\mathrm{SiO}_{2}\right.$, hexane/EtOAc $\left.=3 / 1, \mathrm{v} / \mathrm{v}\right)$ to give compound 5 as a yellow solid in quantitative yield (38 mg). Mp 88$89^{\circ} \mathrm{C}$ (from EtOAc/hexane). IR (KBr) 2970, 2932, 2874, 1735, 1689, 1639, 1427, 1369, 1339, 1285, 1242, 1161, 1062, 840, 774, $722 \mathrm{~cm}^{-1} ;{ }^{1} \mathrm{H} \mathrm{NMR}\left(\mathrm{CDCl}_{3}, 300 \mathrm{MHz}\right) \delta 1.12(\mathrm{t}, J=7.7 \mathrm{~Hz}, 3 \mathrm{H})$, $2.11(\mathrm{~s}, 3 \mathrm{H}), 2.14(\mathrm{~s}, 3 \mathrm{H}), 2.40(\mathrm{q}, J=7.5 \mathrm{~Hz}, 2 \mathrm{H}), 2.58(\mathrm{t}, J=$ $7.6 \mathrm{~Hz}, 2 \mathrm{H}), 3.03(\mathrm{t}, J=7.6 \mathrm{~Hz}, 2 \mathrm{H}), 4.02(\mathrm{br}, 2 \mathrm{H}), 4.58(\mathrm{~d}, J=$ $5.7 \mathrm{~Hz}, 2 \mathrm{H}), 5.23(\mathrm{~d}, J=10.5 \mathrm{~Hz}, 1 \mathrm{H}), 5.29(\mathrm{~d}, J=17.2 \mathrm{~Hz}, 1 \mathrm{H})$, 5.91 (ddt, $J=17.2,10.5,5.7 \mathrm{~Hz}, 1 \mathrm{H}), 5.98$ (s, 1H), 9.70 (s, 1H). The protons of the ethylene bridge were not observed clearly. Found: C, 68.97; $\mathrm{H}, 6.73 ; \mathrm{N}, 7.27 \%$. Calcd for $\mathrm{C}_{22} \mathrm{H}_{26} \mathrm{~N}_{2} \mathrm{O}_{4}$ : C, $69.09 ; \mathrm{H}, 6.85 ; \mathrm{N}, 7.32 \%$.

Allyl 3-\{(Z)-2-\{[(Z)-2-(3-Allyloxy-3-oxopropyl)-9-ethyl-1,10dimethyl-8-oxo-5,6-dihydro-8H-dipyrrolo $\left[1,2-d: 2^{\prime}, 1^{\prime}\right.$ - $\left.g\right][1,4]$ diazepin-3-yl]methylene\}-4-methyl-5-[(Z)-(4-methyl-5-oxo-3-vinyl$1 H$-pyrrol-2(5H)-ylidene)methyl]-2 $H$-pyrrol-3-yl $\}$ propanoate (1b). To a mixed solution of compounds 5 ( $38 \mathrm{mg}, 0.1 \mathrm{mmol})$ and $4(33 \mathrm{mg}, 0.1 \mathrm{mmol})$ in $\mathrm{MeOH}(4 \mathrm{~mL})$, a solution of $\mathrm{H}_{2} \mathrm{SO}_{4}$ (20 mg, $0.2 \mathrm{mmol})$ in $\mathrm{MeOH}(1 \mathrm{~mL})$ was added dropwise at room temperature under $\mathrm{N}_{2}$, and the mixture was allowed to stir for $1 \mathrm{~h}$. The reaction mixture was quenched by addition of a buffer solution ( $\mathrm{pH}$ 7.0) and partitioned between EtOAc and water. The organic layer was washed with brine and dried over $\mathrm{Na}_{2} \mathrm{SO}_{4}$. The solvent was evaporated, and the blue residue was separated by thin layer chromatography $\left(\mathrm{SiO}_{2}\right.$, hexane $/ \mathrm{CHCl}_{3} / \mathrm{MeOH}=7 / 4 / 0.5$, $\mathrm{v} / \mathrm{v} / \mathrm{v}$ ) to afford compound $\mathbf{1 b}$ as a blue solid $(47 \mathrm{mg}, 69 \%)$. Mp 63-65 ${ }^{\circ} \mathrm{C}$ (from EtOAc/hexane). IR (KBr) 3536, 2965, 1733, $1698,1675,1589,1456,1414,1357,1317,1269,1201,1160$, 1104, 986, 961, $932 \mathrm{~cm}^{-1} ;{ }^{1} \mathrm{H} \mathrm{NMR}\left(\mathrm{CDCl}_{3}, 400 \mathrm{MHz}\right) \delta 1.11$ (t, $J=7.3 \mathrm{~Hz}, 3 \mathrm{H}), 2.05(\mathrm{~s}, 3 \mathrm{H}), 2.09(\mathrm{~s}, 3 \mathrm{H}), 2.14(\mathrm{~s}, 3 \mathrm{H}), 2.18$ (s, 3H), 2.39 (q, $J=7.6 \mathrm{~Hz}, 2 \mathrm{H}), 2.53(\mathrm{t}, J=8.1 \mathrm{~Hz}, 2 \mathrm{H}), 2.59$ (t, $J=7.6 \mathrm{~Hz}, 2 \mathrm{H}), 2.96(\mathrm{t}, J=7.6 \mathrm{~Hz}, 2 \mathrm{H}), 2.99(\mathrm{t}, J=7.6 \mathrm{~Hz}$, $2 \mathrm{H}), 3.79-4.24(\mathrm{br}, 2 \mathrm{H}), 4.52(\mathrm{~d}, J=5.6 \mathrm{~Hz}, 2 \mathrm{H}), 4.57(\mathrm{~d}, J=$ $5.6 \mathrm{~Hz}, 2 \mathrm{H}), 5.18(\mathrm{dd}, J=10.3,1.2 \mathrm{~Hz}, 1 \mathrm{H}), 5.20(\mathrm{dd}, J=10.2$, $1.5 \mathrm{~Hz}, 1 \mathrm{H}), 5.23(\mathrm{dd}, J=16.8,1.4 \mathrm{~Hz}, 1 \mathrm{H}), 5.27(\mathrm{dd}, J=17.3$, $1.5 \mathrm{~Hz}, 1 \mathrm{H}), 5.66(\mathrm{~d}, J=11.5 \mathrm{~Hz}, 1 \mathrm{H}), 5.70(\mathrm{~d}, J=18.8 \mathrm{~Hz}, 1 \mathrm{H})$, 5.85 (ddt, $J=16.7,10.8,5.6 \mathrm{~Hz}, 1 \mathrm{H}$ ), 5.88 (ddt, $J=16.1,11.0$, $5.6 \mathrm{~Hz}, 1 \mathrm{H}), 6.03(\mathrm{~s}, 2 \mathrm{H}), 6.62(\mathrm{dd}, J=17.9,11.5 \mathrm{~Hz}, 1 \mathrm{H}), 6.94$ $(\mathrm{s}, 1 \mathrm{H}), 10.49$ (brs, $1 \mathrm{H})$. The protons of the ethylene bridge were not observed clearly. Found: C, 71.24; H, 6.68; N, 8.08\%. Calcd for $\mathrm{C}_{41} \mathrm{H}_{46} \mathrm{~N}_{4} \mathrm{O}_{6}: \mathrm{C}, 71.28 ; \mathrm{H}, 6.71 ; \mathrm{N}, 8.11 \%$.

3-\{(Z)-2-\{[(Z)-2-(2-Carboxyethyl)-9-ethyl-1,10-dimethyl-8oxo-5,6-dihydro-8H-dipyrrolo[1,2- $\left.d: 2^{\prime}, 1^{\prime}-g\right][1,4]$ diazepin-3-yl]methylene $\}$-4-methyl-5-[(Z)-(4-methyl-5-oxo-3-vinyl-1H-pyrrol2(5H)-ylidene)methyl]-2H-pyrrol-3-yl\}propanoic Acid (1a). To a mixed solution of $\mathbf{1 b}(38 \mathrm{mg}, 0.05 \mathrm{mmol})$ and $\left[\mathrm{Pd}\left(\mathrm{PPh}_{3}\right)_{4}\right]$ $(13 \mathrm{mg}, 0.011 \mathrm{mmol})$ in THF $(1.4 \mathrm{~mL})$, a solution of NaTs $(20 \mathrm{mg}$, $0.11 \mathrm{mmol})$ in $\mathrm{MeOH}(1.4 \mathrm{~mL})$ was added at room temperature under $\mathrm{N}_{2}$. After stirring for $10 \mathrm{~min}$, the solvent was evaporated, and the residue was separated by flash column chromatography $\left(\mathrm{SiO}_{2}\right.$, $\mathrm{CHCl}_{3} / \mathrm{MeOH} / \mathrm{AcOH}=200 / 15 / 1, \mathrm{v} / \mathrm{v} / \mathrm{v}$ ). The solvent of the blue fraction was evaporated, and the resulting solid residue was recrystallized from $\mathrm{CHCl}_{3}$ /hexane to afford compound $\mathbf{1 a}$ as a blue solid (24 mg, 80\%). Decomposed above $270{ }^{\circ} \mathrm{C}$. IR (KBr) 3537, 3265, 3022, 2944, 2293, 2253, 1931, 1443, 1375, 1230, $1038,919,759,668 \mathrm{~cm}^{-1} ;{ }^{1} \mathrm{H}$ NMR $\left(\mathrm{C}_{5} \mathrm{D}_{5} \mathrm{~N}, 400 \mathrm{MHz}\right) \delta 1.03$ $(\mathrm{t}, J=7.6 \mathrm{~Hz}, 3 \mathrm{H}), 1.90(\mathrm{~s}, 3 \mathrm{H}), 1.98(\mathrm{~s}, 3 \mathrm{H}), 2.11(\mathrm{~s}, 3 \mathrm{H}), 2.16$ (s, 3H), 2.33 (q, $J=7.6 \mathrm{~Hz}, 2 \mathrm{H}), 2.85(\mathrm{t}, J=7.3 \mathrm{~Hz}, 2 \mathrm{H}), 2.91$ (t,
$J=7.3 \mathrm{~Hz}, 2 \mathrm{H}), 3.24(\mathrm{t}, J=7.3 \mathrm{~Hz}, 2 \mathrm{H}), 3.34(\mathrm{t}, J=7.3 \mathrm{~Hz}$, $2 \mathrm{H}), 4.52(\mathrm{br}, 2 \mathrm{H}), 4.84(\mathrm{br}, 2 \mathrm{H}), 5.56(\mathrm{~d}, J=11.7 \mathrm{~Hz}, 1 \mathrm{H})$, $5.63(\mathrm{~d}, J=17.8 \mathrm{~Hz}, 1 \mathrm{H}), 5.99(\mathrm{~s}, 1 \mathrm{H}), 6.26(\mathrm{~s}, 1 \mathrm{H}), 6.68(\mathrm{dd}$, $J=17.8,11.5 \mathrm{~Hz}, 1 \mathrm{H}), 7.62(\mathrm{~s}, 1 \mathrm{H})$. Protons of $\mathrm{CO}_{2} \underline{\mathrm{H}}$ and $\mathrm{NH}$ were not observed clearly. UV-vis $(\mathrm{MeOH}) \lambda_{\max } 383(\varepsilon=$ 39850), $639(\varepsilon=18650) \mathrm{nm}$. HRMS (FAB) $\left(\mathrm{M}^{+}+1\right)$, Found: $m / z$ 611.2876. Calcd for $\mathrm{C}_{35} \mathrm{H}_{39} \mathrm{~N}_{4} \mathrm{O}_{6}$ : 611.2869.

3-Nitropropyl Acetate (16). To a mixed solution of DMAP (1.952 g, $16 \mathrm{mmol}$ ) and 3-bromopropan-1-ol 15 (11.12 g, $80 \mathrm{mmol})$ in THF $(40 \mathrm{~mL})$ was added $\mathrm{Ac}_{2} \mathrm{O}(9.7 \mathrm{~mL}, 88 \mathrm{mmol})$ dropwise under $\mathrm{N}_{2}$ at $0{ }^{\circ} \mathrm{C}$. After stirring for $30 \mathrm{~min}$ at $0{ }^{\circ} \mathrm{C}$ and $2.5 \mathrm{~h}$ at room temperature, the solvent was removed under reduced pressure, and the residue was partitioned between EtOAc and water. The organic extract was washed with a saturated aqueous solution of $\mathrm{NaHCO}_{3}$ and with brine, and dried over $\mathrm{MgSO}_{4}$. The solvent was evaporated to give the acetylated product $(12.742 \mathrm{~g}, 88 \%$ ) as a colorless oil, which was used for the next reaction without further purification. IR (neat) 2966, 2902, 1741, 1439, 1387, 1366, 1238, $1037 \mathrm{~cm}^{-1}$; ${ }^{1} \mathrm{HNMR}\left(\mathrm{CDCl}_{3}, 300 \mathrm{MHz}\right) \delta 2.06(\mathrm{~s}, 3 \mathrm{H})$, 2.18 (quint, $J=6.2 \mathrm{~Hz}, 2 \mathrm{H}), 3.47(\mathrm{t}, J=6.5 \mathrm{~Hz}, 2 \mathrm{H}), 4.20(\mathrm{t}, J=$ $6.1 \mathrm{~Hz}, 2 \mathrm{H}) \mathrm{ppm}$. The resulting 3-bromopropyl acetate $(12.62 \mathrm{~g}$, $70 \mathrm{mmol})$ was treated with $\mathrm{NaNO}_{2}(9.62 \mathrm{~g}, 140 \mathrm{mmol})$ and phloroglucinol (12.472 g, $77 \mathrm{mmol})$ under $\mathrm{N}_{2}$ in DMF (100 mL), and the mixture was allowed to stir overnight at room temperature. The mixture was then partitioned between EtOAc/ $\mathrm{Et}_{2} \mathrm{O}$ and water, and the organic extract was washed with brine and dried over $\mathrm{MgSO}_{4}$. The solvent was evaporated, and the product was purified by flash column chromatography $\left(\mathrm{SiO}_{2}\right.$, hexane $/ \mathrm{EtOAc}=2 / 1$, $\mathrm{v} / \mathrm{v})$ to give compound $\mathbf{1 6}$ as an oil in $60 \%$ yield $(6.174 \mathrm{~g})$; IR (neat) 2253, 1740, 1556, 1363, $1223 \mathrm{~cm}^{-1} ;{ }^{1} \mathrm{H} \mathrm{NMR}\left(\mathrm{CDCl}_{3}, 300\right.$ MHz) $\delta 2.07(\mathrm{~s}, 3 \mathrm{H}), 2.36$ (quint, $J=6.6 \mathrm{~Hz}, 2 \mathrm{H}), 4.19$ (t, $J=$ $6.1 \mathrm{~Hz}, 2 \mathrm{H}), 4.50(\mathrm{t}, J=6.8 \mathrm{~Hz}, 2 \mathrm{H})$. HRMS (TOF) $\left(\mathrm{M}^{+}+1\right)$, Found: $m / z$ 148.0641. Calcd for $\mathrm{C}_{5} \mathrm{H}_{10} \mathrm{NO}_{4}$ : 148.0610 .

$\boldsymbol{t}$-Butyl 4-(2-Acetoxyethyl)-3-(3-methoxy-3-oxopropyl)-1Hpyrrole-2-carboxylate (19). To a mixture of methyl 4-oxobutanoate 17 (2.32 g, $20 \mathrm{mmol})$ and compound 16 (2.94 g, $20 \mathrm{mmol})$, a solution of $\mathrm{KOH}(131 \mathrm{mg}, 2 \mathrm{mmol})$ in $\mathrm{MeOH}(3 \mathrm{~mL})$ was added dropwise at $0{ }^{\circ} \mathrm{C}$, and the mixture was allowed to stir overnight at room temperature. After evaporation of the solvent, the residue was partitioned between EtOAc and water. The organic layer was washed with a saturated aqueous solution of $\mathrm{NaHCO}_{3}$ and with brine, and dried over $\mathrm{MgSO}_{4}$. The solvent was evaporated to give the nitro-alcohol as a crude product. This product was mixed with DMAP $(488 \mathrm{mg}, 4 \mathrm{mmol})$ in $\mathrm{THF}(15 \mathrm{~mL})$ at $0^{\circ} \mathrm{C}$, and $\mathrm{Ac}_{2} \mathrm{O}$ $(2.1 \mathrm{~mL}, 22 \mathrm{mmol})$ was added dropwise with stirring at room temperature. After stirring for $4 \mathrm{~h}$, the mixture was quenched by $\mathrm{MeOH}(2 \mathrm{~mL})$ for $15 \mathrm{~min}$. The solvent was removed under reduced pressure and the residue was partitioned between EtOAc and water. The organic extract was washed with both a saturated aqueous solution of $\mathrm{NaHCO}_{3}$ and brine, and dried over $\mathrm{MgSO}_{4}$. The solvent was evaporated, and the product was isolated by flash column chromatography $\left(\mathrm{SiO}_{2}\right.$, hexane/EtOAc $\left.=3 / 1, \mathrm{v} / \mathrm{v}\right)$ to give a mixture of diastereomers of compound $\mathbf{1 8}(4.03 \mathrm{~g}$, ca. $66 \%$ yield) contaminated with the corresponding nitro-olefin as an oil.

To a solution of $t$-butyl isocyanoacetate $(1.27 \mathrm{~g}, 9 \mathrm{mmol})$ in $\operatorname{MeCN}(10 \mathrm{~mL})$ at $-40{ }^{\circ} \mathrm{C}$ under $\mathrm{N}_{2}$, DBU $(2.95 \mathrm{~mL}, 19.8 \mathrm{mmol})$ was added, followed by dropwise addition of compound $\mathbf{1 8}$ $(2.748 \mathrm{~g}, 9 \mathrm{mmol})$ in $\mathrm{MeCN}(5 \mathrm{~mL})$. After stirring for $6 \mathrm{~h}$ at room temperature, the solvent was removed under reduced pressure, and the residue was partitioned between EtOAc and water. The extract was successively washed with a saturated aqueous solution of $\mathrm{NaHSO}_{3}$, a solution of $\mathrm{NaHCO}_{3}$, and brine, and then dried over 
$\mathrm{MgSO}_{4}$. The solvent was evaporated, and the residue was separated by flash column chromatography $\left(\mathrm{SiO}_{2}\right.$, hexane $/$ EtOAc $=4 / 1$, $\mathrm{v} / \mathrm{v})$ to give compound $\mathbf{1 9}(1.69 \mathrm{~g}, 55 \%)$ as an oil. IR (neat) 3320 , 2977, 2936, 1737, 1720, 1684, 1455, 1408, 1368, 1243, 1135, 1050, $933 \mathrm{~cm}^{-1} ;{ }^{1} \mathrm{HNMR}\left(\mathrm{CDCl}_{3}, 400 \mathrm{MHz}\right) \delta 1.57$ (s, 9H), 2.05 $(\mathrm{s}, 3 \mathrm{H}), 2.53(\mathrm{t}, J=8.2 \mathrm{~Hz}, 2 \mathrm{H}), 2.78(\mathrm{t}, J=7.1 \mathrm{~Hz}, 2 \mathrm{H}), 3.01(\mathrm{t}$, $J=8.1 \mathrm{~Hz}, 2 \mathrm{H}), 3.67(\mathrm{~s}, 3 \mathrm{H}), 4.18(\mathrm{t}, J=7.1 \mathrm{~Hz}, 2 \mathrm{H}), 6.71(\mathrm{~d}$, $J=2.9 \mathrm{~Hz}, 1 \mathrm{H}), 9.10$ (brs, 1H). HRMS (TOF) $\left(\mathrm{M}^{+}+1\right)$, Found: $m / z$ 340.1775. Calcd for $\mathrm{C}_{17} \mathrm{H}_{26} \mathrm{NO}_{6}: 340.1760$.

t-Butyl 3-(3-Allyloxy-3-oxopropyl)-4-(2-hydroxyethyl)-1H pyrrole-2-carboxylate (20). To a solution of compound 19 $(1.565 \mathrm{~g}, 4.6 \mathrm{mmol})$ in $\mathrm{MeOH}(20 \mathrm{~mL})$, a $3 \mathrm{M} \mathrm{KOH}$ solution in $\mathrm{MeOH}(7.7 \mathrm{~mL}, 23 \mathrm{mmol})$ was added dropwise at $0{ }^{\circ} \mathrm{C}$. After stirring for $2 \mathrm{~h}$, the solvent was evaporated. The residue was acidified (pH 3-4) with $1 \mathrm{M} \mathrm{HCl}$ and extracted with EtOAc. The extract was washed with brine and dried over $\mathrm{MgSO}_{4}$. The solvent was evaporated to afford a crude product. To a solution of the product in THF/DMF $(20 / 10 \mathrm{~mL})$, DBU $(0.7 \mathrm{~mL}, 4.6 \mathrm{mmol})$ was added dropwise at $0{ }^{\circ} \mathrm{C}$ under $\mathrm{N}_{2}$, followed by dropwise addition of allyl bromide $(0.44 \mathrm{~mL}, 5.1 \mathrm{mmol})$, and the mixture was allowed to stir for $1.5 \mathrm{~h}$ at room temperature. The solvent was removed under reduced pressure, and the residue was partitioned between EtOAc and water. The organic layer was washed with brine and dried over $\mathrm{MgSO}_{4}$. The residue that was obtained by evaporating the solvent was separated by flash column chromatography $\left(\mathrm{SiO}_{2}\right.$, hexane $/$ EtOAc $=3 / 1, \mathrm{v} / \mathrm{v})$ to afford compound $20(0.89 \mathrm{~g}, 60 \%$ in two steps) as an oil. IR (neat) 3346, 2978, 2935, 1738, 1714, 1407, 1223, 1172, 1133, 1051, $933 \mathrm{~cm}^{-1} ;{ }^{1} \mathrm{HNMR}\left(\mathrm{CDCl}_{3}, 300\right.$ MHz) $\delta 1.57(\mathrm{~s}, 9 \mathrm{H}), 2.58(\mathrm{t}, J=8.1 \mathrm{~Hz}, 2 \mathrm{H}), 2.71(\mathrm{t}, J=6.5 \mathrm{~Hz}$, $2 \mathrm{H}), 3.02(\mathrm{t}, J=8.1 \mathrm{~Hz}, 2 \mathrm{H}), 3.75(\mathrm{t}, J=6.5 \mathrm{~Hz}, 2 \mathrm{H}), 4.58(\mathrm{dt}$, $J=5.7,1.3 \mathrm{~Hz}, 2 \mathrm{H}), 5.22(\mathrm{dq}, J=10.5,1.5 \mathrm{~Hz}, 1 \mathrm{H}), 5.29(\mathrm{dq}$, $J=17.2,1.5 \mathrm{~Hz}, 1 \mathrm{H}), 5.91$ (ddt, $J=17.2,10.5,5.7 \mathrm{~Hz}, 1 \mathrm{H}), 6.73$ (d, $J=2.9 \mathrm{~Hz}, 1 \mathrm{H}), 9.34$ (brs, 1H). HRMS (TOF) $\left(\mathrm{M}^{+}+1\right)$, Found: $m / z$ 324.1835. Calcd for $\mathrm{C}_{17} \mathrm{H}_{26} \mathrm{NO}_{5}$ : 324.1811 .

t-Butyl 3-(3-Allyloxy-3-oxopropyl)-4-(2-chloroethyl)-5-formyl-1H-pyrrole-2-carboxylate (10b). To DMF $(8 \mathrm{~mL})$ was added $\mathrm{POCl}_{3}(0.26 \mathrm{~mL}, 2.8 \mathrm{mmol})$ dropwise, and the mixture was stirred for $10 \mathrm{~min}$ at $0{ }^{\circ} \mathrm{C}$ and for additional $10 \mathrm{~min}$ at room temperature. A solution of compound $20(362 \mathrm{mg}, 1.12 \mathrm{mmol})$ in DMF $(8 \mathrm{~mL})$ was then added dropwise at $0{ }^{\circ} \mathrm{C}$ and the mixture was stirred for $10 \mathrm{~min}$ at $0^{\circ} \mathrm{C}$ and $2 \mathrm{~h}$ at $80^{\circ} \mathrm{C}$. The reaction mixture was quenched by addition of a $10 \%$ aqueous $\mathrm{NaOAc}$ and stirred for $2 \mathrm{~h}$ at room temperature. The mixture was partitioned between EtOAc and water, and the organic extract was washed with brine and dried over $\mathrm{MgSO}_{4}$. The solvent was evaporated, and the product was purified by flash column chromatography $\left(\mathrm{SiO}_{2}\right.$, hexane/ EtOAc $=3 / 1, \mathrm{v} / \mathrm{v})$ to give compound $\mathbf{1 0 b}(393 \mathrm{mg}, 94 \%)$ as an oil. IR (neat) 3284, 2978, 2359, 1735, 1705, 1667, 1458, 1369, 1272, 1158, 1078, 932, $844 \mathrm{~cm}^{-1} ;{ }^{1} \mathrm{HNMR}\left(\mathrm{CDCl}_{3}, 400 \mathrm{MHz}\right)$ $\delta 1.59(\mathrm{~s}, 9 \mathrm{H}), 2.63(\mathrm{t}, J=7.8 \mathrm{~Hz}, 2 \mathrm{H}), 3.02(\mathrm{t}, J=7.7 \mathrm{~Hz}, 2 \mathrm{H})$, $3.24(\mathrm{t}, J=6.8 \mathrm{~Hz}, 2 \mathrm{H}), 3.67(\mathrm{t}, J=6.9 \mathrm{~Hz}, 2 \mathrm{H}), 4.58(\mathrm{dt}, J=$ $5.6,1.5 \mathrm{~Hz}, 2 \mathrm{H}), 5.23(\mathrm{dq}, J=10.3,1.2 \mathrm{~Hz}, 1 \mathrm{H}), 5.30(\mathrm{dq}, J=$ $17.3,1.4 \mathrm{~Hz}, 1 \mathrm{H}), 5.90$ (ddt, $J=17.3,10.5,5.6 \mathrm{~Hz}, 1 \mathrm{H}$ ), 9.67 (brs, $1 \mathrm{H}), 9.77(\mathrm{~s}, 1 \mathrm{H})$. HRMS (TOF) $\left(\mathrm{M}^{+}+1\right)$, Found: $m / z 370.1501$ $\left({ }^{35} \mathrm{Cl}\right), 372.1491\left({ }^{37} \mathrm{Cl}\right)$. Calcd for $\mathrm{C}_{18} \mathrm{H}_{25}{ }^{35} \mathrm{ClNO}_{5}$ : 370.1421 , $\mathrm{C}_{18} \mathrm{H}_{25}{ }^{37} \mathrm{ClNO}_{5}$ : 372.1392 .

$t$-Butyl 3-(3-Allyloxy-3-oxopropyl)-4-(2-chloroethyl)-5-[(4ethyl-3-methyl-5-oxo- $1 H$-pyrrol-2(5H)-ylidene)methyl]- $1 H$-pyrrole-2-carboxylate $(\mathbf{8 b})$. To a mixed solution of 5-tosylpyrrolinone 9a $(125 \mathrm{mg}, 0.44 \mathrm{mmol})$ and formylpyrrole $\mathbf{1 0 b}(138 \mathrm{mg}$, $0.37 \mathrm{mmol})$ in THF $(8 \mathrm{~mL}),{ }^{n} \mathrm{Bu}_{3} \mathrm{P}(0.23 \mathrm{~mL}, 0.93 \mathrm{mmol})$ was added dropwise at $0{ }^{\circ} \mathrm{C}$ under $\mathrm{N}_{2}$, followed by dropwise addition of a solution of DBU ( $83 \mathrm{mg}, 0.56 \mathrm{mmol})$ in THF $(2 \mathrm{~mL})$. The reaction mixture was allowed to stir for $4 \mathrm{~h}$ at room temperature. The solvent was removed under reduced pressure, and the residue was partitioned between EtOAc and water. The organic layer was washed with a saturated aqueous solution of $\mathrm{NH}_{4} \mathrm{Cl}$ and with brine, and dried over $\mathrm{MgSO}_{4}$. The solvent was evaporated, and the residue was separated by flash column chromatography $\left(\mathrm{SiO}_{2}\right.$, hexane $/$ EtOAc $=4 / 1, \mathrm{v} / \mathrm{v}$ ) to give $\mathbf{8 b}$ as a yellow solid mixture $(175 \mathrm{mg}, 98 \%)$ of $(Z)-(14 \%)$ and $(E)$-isomers $(84 \%)$. IR $(\mathrm{KBr})$ 3335, 2974, 2931, 1733, 1693, 1654, 1450, 1392, 1368, 1281, $1162,1136,1080,987,847,779,717,685 \mathrm{~cm}^{-1}$. The $(Z)-$ and (E)-isomers were further separated by repeating the flash column chromatography with a longer column under the same conditions. ${ }^{1} \mathrm{HNMR}\left(\mathrm{CDCl}_{3}, 400 \mathrm{MHz}\right)(E)-8 \mathbf{b}: \delta 1.07$ (t, $\left.J=7.6 \mathrm{~Hz}, 3 \mathrm{H}\right)$, $1.54(\mathrm{~s}, 9 \mathrm{H}), 2.11(\mathrm{~s}, 3 \mathrm{H}), 2.44(\mathrm{q}, J=7.6 \mathrm{~Hz}, 2 \mathrm{H}), 2.59(\mathrm{t}$, $J=7.6 \mathrm{~Hz}, 2 \mathrm{H}), 3.00(\mathrm{t}, J=7.6 \mathrm{~Hz}, 2 \mathrm{H}), 3.01(\mathrm{t}, J=7.6 \mathrm{~Hz}$, $2 \mathrm{H}), 3.45(\mathrm{t}, J=7.6 \mathrm{~Hz}, 2 \mathrm{H}), 4.58(\mathrm{~d}, J=5.6 \mathrm{~Hz}, 2 \mathrm{H}), 5.22(\mathrm{dd}$, $J=10.5,1.2 \mathrm{~Hz}, 1 \mathrm{H}), 5.30(\mathrm{dd}, J=17.1,1.5 \mathrm{~Hz}, 1 \mathrm{H}), 5.91$ (ddt, $J=16.9,10.0,5.6 \mathrm{~Hz}, 1 \mathrm{H}), 5.94(\mathrm{~s}, 1 \mathrm{H}), 10.04(\mathrm{~s}, 1 \mathrm{H}), 10.33(\mathrm{~s}$, 1H). (Z)-8b: $\delta 1.07$ (t, $J=7.6 \mathrm{~Hz}, 3 \mathrm{H}), 1.56(\mathrm{~s}, 9 \mathrm{H}), 1.78(\mathrm{~s}, 3 \mathrm{H})$, $2.33(\mathrm{q}, J=7.6 \mathrm{~Hz}, 2 \mathrm{H}), 2.61(\mathrm{t}, J=8.0 \mathrm{~Hz}, 2 \mathrm{H}), 2.91(\mathrm{t}, J=7.5$ $\mathrm{Hz}, 2 \mathrm{H}), 3.01$ (t, $J=8.0 \mathrm{~Hz}, 2 \mathrm{H}), 3.53$ (t, $J=7.5 \mathrm{~Hz}, 2 \mathrm{H}), 4.59$ $(\mathrm{dt}, J=5.9,1.4 \mathrm{~Hz}, 2 \mathrm{H}), 5.23(\mathrm{dq}, J=10.5,1.2 \mathrm{~Hz}, 1 \mathrm{H}), 5.31$ $(\mathrm{dq}, J=17.1,1.4 \mathrm{~Hz}, 1 \mathrm{H}), 5.92(\mathrm{ddt}, J=17.3,10.2,5.9 \mathrm{~Hz}, 1 \mathrm{H})$, $6.20(\mathrm{~s}, 1 \mathrm{H}), 9.08(\mathrm{~s}, 1 \mathrm{H}), 9.56(\mathrm{~s}, 1 \mathrm{H})$. Compound $(E)-8 \mathbf{b}$ was converted to its isomer $(Z)-\mathbf{8 b}$ as follows: A mixed solution of compound $(E)-8 \mathbf{b}(26 \mathrm{mg}, 0.05 \mathrm{mmol})$ and iodine $(5 \mathrm{mg}, 0.015$ $\mathrm{mmol})$ in $\mathrm{CH}_{2} \mathrm{Cl}_{2}(3 \mathrm{~mL})$ was stirred for $24 \mathrm{~h}$ at room temperature. The solvent was removed under reduced pressure, and the residue was partitioned between EtOAc and water. The organic layer was washed with both a saturated aqueous solution of $\mathrm{NaHSO}_{3}$ and brine, and dried over $\mathrm{MgSO}_{4}$. The solvent was evaporated, and the residue was separated by flash column chromatography $\left(\mathrm{SiO}_{2}\right.$, hexane $/ \mathrm{EtOAc}=4 / 1, \mathrm{v} / \mathrm{v})$ to give compound $(Z)-\mathbf{8 b}$ in $80 \%$ yield (21 mg). Mp $137-138{ }^{\circ} \mathrm{C}$ (from EtOAc/hexane). Found: $\mathrm{C}$, 62.90; H, 6.97; N, 5.81\%. Calcd for $\mathrm{C}_{25} \mathrm{H}_{33} \mathrm{ClN}_{2} \mathrm{O}_{5}$ : C, 62.95; $\mathrm{H}, 6.97 ; \mathrm{N}, 5.87 \%$.

t-Butyl (Z)-3-(3-Allyloxy-3-oxopropyl)-8-ethyl-9-methyl-7oxo-1,4,5,7-tetrahydrodipyrrolo[1,2- $a: 2^{\prime}, 3^{\prime}$-d $]$ azepine-2-carboxylate (21). To a solution of compound (Z)-8b (490 mg, $1.0 \mathrm{mmol})$ in THF $(20 \mathrm{~mL})$, DBU $(0.46 \mathrm{~mL}, 3.0 \mathrm{mmol})$ was added under $\mathrm{N}_{2}$, and the mixture was allowed to stir at $50^{\circ} \mathrm{C}$ overnight. The solvent was removed under reduced pressure, and the residue was partitioned between EtOAc and water. The organic layer was washed with brine and dried over $\mathrm{MgSO}_{4}$. The solvent was evaporated, and the residue was separated by flash column chromatography $\left(\mathrm{SiO}_{2}\right.$, hexane $\left./ \mathrm{EtOAc}=4 / 1, \mathrm{v} / \mathrm{v}\right)$ to give the product $\mathbf{2 1}$ in $76 \%$ yield $\left(335 \mathrm{mg}\right.$ ) as a yellow solid. $\mathrm{Mp} 73-75^{\circ} \mathrm{C}$ (from EtOAc/ hexane). IR (KBr) 3261, 2974, 2933, 1736, 1656, 1559, 1450, 1367, 1327, 1283, 1166, 1135, 1094, $993 \mathrm{~cm}^{-1} ;{ }^{1} \mathrm{HNMR}\left(\mathrm{CDCl}_{3}\right.$, $400 \mathrm{MHz}) \delta 1.07(\mathrm{t}, J=7.6 \mathrm{~Hz}, 3 \mathrm{H}), 1.60(\mathrm{~s}, 9 \mathrm{H}), 2.05(\mathrm{~s}, 3 \mathrm{H})$, $2.39(\mathrm{q}, J=7.6 \mathrm{~Hz}, 2 \mathrm{H}), 2.59(\mathrm{t}, J=7.8 \mathrm{~Hz}, 2 \mathrm{H}), 2.87$ (brt, $J=$ $4.6 \mathrm{~Hz}, 2 \mathrm{H}), 3.04(\mathrm{t}, J=7.8 \mathrm{~Hz}, 2 \mathrm{H}), 3.94(\mathrm{br}, 2 \mathrm{H}), 4.59(\mathrm{~d}$, $J=5.6 \mathrm{~Hz}, 2 \mathrm{H}), 5.22(\mathrm{dd}, J=10.5,1.2 \mathrm{~Hz}, 1 \mathrm{H}), 5.30(\mathrm{dd}, J=$ $17.1,1.5 \mathrm{~Hz}, 1 \mathrm{H}), 5.91$ (ddt, $J=17.1,10.4,5.6 \mathrm{~Hz}, 1 \mathrm{H}), 6.12$ (s, 1H), 10.10 (s, 1H). Found: C, 68.09; H, 7.24; N, 6.32\%. Calcd for $\mathrm{C}_{25} \mathrm{H}_{32} \mathrm{~N}_{2} \mathrm{O}_{5}$ : C, 68.16; H, 7.32; N, 6.36\%.

Allyl (Z)-3-(8-Ethyl-2-formyl-9-methyl-7-oxo-1,4,5,7-tetrahydrodipyrrolo[1,2-a:2', $3^{\prime}$ - $\left.d\right]$ azepin-3-yl)propanoate (6). After treating compound $21(270 \mathrm{mg}, 0.61 \mathrm{mmol})$ in TFA $(6 \mathrm{~mL})$ at room temperature for 30 min under $\mathrm{N}_{2},\left(\mathrm{CH}_{3} \mathrm{O}\right)_{3} \mathrm{CH}(3 \mathrm{~mL})$ was added dropwise at $0^{\circ} \mathrm{C}$, and the mixture was allowed to stir at 
room temperature for $1 \mathrm{~h}$. The reaction mixture was quenched with water and extracted with EtOAc. The organic layer was washed with both a saturated aqueous solution of $\mathrm{NaHCO}_{3}$ and brine, and dried over $\mathrm{MgSO}_{4}$. The solvent was evaporated, and the residue was separated by flash column chromatography $\left(\mathrm{SiO}_{2}\right.$, hexane $/ \mathrm{EtOAc}=3 / 1, \mathrm{v} / \mathrm{v}$ ) to give compound $\mathbf{6}$ in quantitative yield $\left(221 \mathrm{mg}\right.$ ) as a yellow solid. Mp $97-99^{\circ} \mathrm{C}$ (from EtOAc/ hexane). IR (KBr) 3249, 2925, 2875, 1739, 1695, 1612, 1453, 1411, 1388, 1327, 1184, 1142, 964, 936, 853, 836, 778, $748 \mathrm{~cm}^{-1}$; ${ }^{1} \mathrm{HNMR}\left(\mathrm{CDCl}_{3}, 400 \mathrm{MHz}\right) \delta 1.12(\mathrm{t}, J=7.5 \mathrm{~Hz}, 3 \mathrm{H}), 2.10(\mathrm{~s}$, $3 \mathrm{H}), 2.40(\mathrm{q}, J=7.5 \mathrm{~Hz}, 2 \mathrm{H}), 2.62(\mathrm{t}, J=7.3 \mathrm{~Hz}, 2 \mathrm{H}), 2.86$ (brt, $2 \mathrm{H}), 3.07(\mathrm{t}, J=7.3 \mathrm{~Hz}, 2 \mathrm{H}), 3.94(\mathrm{br}, 2 \mathrm{H}), 4.56(\mathrm{~d}, J=5.7 \mathrm{~Hz}$, $2 \mathrm{H}), 5.22(\mathrm{dd}, J=10.4,1.4 \mathrm{~Hz}, 1 \mathrm{H}), 5.28(\mathrm{dd}, J=17.2,1.4 \mathrm{~Hz}$, $1 \mathrm{H}$ ), 5.88 (ddt, $J=17.2,10.4,5.7 \mathrm{~Hz}, 1 \mathrm{H}), 6.30$ (s, 1H), 9.59 (s, $1 \mathrm{H}), 11.07$ (s, 1H). Found: C, 68.38; H, 6.51; N, 7.54\%. Calcd for $\mathrm{C}_{21} \mathrm{H}_{24} \mathrm{~N}_{2} \mathrm{O}_{4}$ : C, 68.46; H, 6.57; N, 7.60\%.

Allyl 3-\{(Z)-2-[(Z)-\{3-(3-Allyloxy-3-oxopropyl)-4-methyl-5[(Z)-(4-methyl-5-oxo-3-vinyl-1H-pyrrol-2(5H)-ylidene)methyl]$2 H$-pyrrol-2-ylidene \}methyl]-8-ethyl-9-methyl-7-oxo-1,4,5,7tetrahydrodipyrrolo[1,2-a:2',3'-d]azepin-3-yl\}propanoate (2b). To a mixed solution of compounds $\mathbf{6}(135 \mathrm{mg}, 0.36 \mathrm{mmol})$ and $4(100 \mathrm{mg}, 0.31 \mathrm{mmol})$ in $\mathrm{MeOH}(13 \mathrm{~mL})$, a solution of $\mathrm{H}_{2} \mathrm{SO}_{4}$ (60 mg, $0.62 \mathrm{mmol})$ in $\mathrm{MeOH}(2 \mathrm{~mL})$ was added dropwise at room temperature under $\mathrm{N}_{2}$. After stirring for $1 \mathrm{~h}$, the reaction mixture was quenched with a buffer solution $(\mathrm{pH} 7.0)$ and extracted with EtOAc. The organic layer was washed with brine and dried over $\mathrm{Na}_{2} \mathrm{SO}_{4}$. The solvent was evaporated, and the blue residue was separated by thin layer chromatography $\left(\mathrm{SiO}_{2}\right.$, hexane $/ \mathrm{CHCl}_{3} /$ $\mathrm{MeOH}=7 / 4 / 0.5, \mathrm{v} / \mathrm{v} / \mathrm{v})$ to afford compound $2 \mathbf{b}$ in $87 \%$ yield $\left(181 \mathrm{mg}\right.$ ) as a blue solid. $\mathrm{Mp} 181-183{ }^{\circ} \mathrm{C}$ (from $\mathrm{CH}_{2} \mathrm{Cl}_{2}$ / hexane); IR (KBr) 3444, 2925, 1730, 1686, 1589, 1456, 1415, 1274, 1177, 1098, 960, 916, $833 \mathrm{~cm}^{-1} ;{ }^{1} \mathrm{HNMR}\left(\mathrm{CDCl}_{3}, 400\right.$ MHz) $\delta 1.11(\mathrm{t}, J=7.6 \mathrm{~Hz}, 3 \mathrm{H}), 2.08(\mathrm{~s}, 3 \mathrm{H}), 2.09(\mathrm{~s}, 3 \mathrm{H}), 2.21$ (s, 3H), $2.40(\mathrm{q}, J=7.6 \mathrm{~Hz}, 2 \mathrm{H}), 2.58(\mathrm{t}, J=7.6 \mathrm{~Hz}, 4 \mathrm{H}), 2.87$ (brt, $J=5.1 \mathrm{~Hz}, 2 \mathrm{H}), 2.92(\mathrm{t}, J=7.7 \mathrm{~Hz}, 2 \mathrm{H}), 2.96(\mathrm{t}, J=7.6$ $\mathrm{Hz}, 2 \mathrm{H}), 3.94$ (br, 2H), $4.56(\mathrm{~d}, J=5.6 \mathrm{~Hz}, 2 \mathrm{H}), 4.57$ (d, $J=5.7$ $\mathrm{Hz}, 2 \mathrm{H}), 5.20(\mathrm{~d}, J=10.4 \mathrm{~Hz}, 2 \mathrm{H}), 5.26(\mathrm{dd}, J=17.2,1.5 \mathrm{~Hz}$, $1 \mathrm{H}), 5.28(\mathrm{dd}, J=17.2,1.5 \mathrm{~Hz}, 1 \mathrm{H}), 5.68(\mathrm{~d}, J=10.8 \mathrm{~Hz}, 1 \mathrm{H})$, $5.71(\mathrm{~d}, J=17.5 \mathrm{~Hz}, 1 \mathrm{H}), 5.87(\mathrm{ddt}, J=17.2,10.4,5.6 \mathrm{~Hz}, 1 \mathrm{H})$, $5.89(\mathrm{ddt}, J=17.2,10.4,5.7 \mathrm{~Hz}, 1 \mathrm{H}), 6.07(\mathrm{~s}, 1 \mathrm{H}), 6.28(\mathrm{~s}, 1 \mathrm{H})$, $6.64(\mathrm{dd}, J=17.5,10.8 \mathrm{~Hz}, 1 \mathrm{H}), 6.81(\mathrm{~s}, 1 \mathrm{H}) . \mathrm{NH}$ protons were not observed clearly. Found: C, 70.95; H, 6.51; N, 8.23\%. Calcd for $\mathrm{C}_{40} \mathrm{H}_{44} \mathrm{~N}_{4} \mathrm{O}_{6}$ : C, 70.99; $\mathrm{H}, 6.55 ; \mathrm{N}, 8.28 \%$.

3-\{(Z)-2-[(Z)-\{3-(2-Carboxyethyl)-4-methyl-5-[(Z)-(4-methyl5-oxo-3-vinyl-1 $H$-pyrrol-2(5H)-ylidene)methyl]-2H-pyrrol-2ylidene\}methyl]-8-ethyl-9-methyl-7-oxo-1,4,5,7-tetrahydrodipyrrolo[1,2-a:2',3'-d]azepin-3-yl\}propanoic Acid (2a). To a mixed solution of compound $\mathbf{2 b}(50 \mathrm{mg}, 0.074 \mathrm{mmol})$ and $\left[\mathrm{Pd}\left(\mathrm{PPh}_{3}\right)_{4}\right](17 \mathrm{mg}, 0.015 \mathrm{mmol})$ in THF $(1.9 \mathrm{~mL})$, a solution of NaTs $(27 \mathrm{mg}, 0.155 \mathrm{mmol})$ in $\mathrm{MeOH}(1.9 \mathrm{~mL})$ was added under $\mathrm{N}_{2}$ at room temperature. After stirring for $10 \mathrm{~min}$, the solvent was evaporated, and the residue was separated by flash column chromatography $\left(\mathrm{SiO}_{2}, \mathrm{CHCl}_{3} / \mathrm{MeOH} / \mathrm{AcOH}=200 / 15 / 1, \mathrm{v} / \mathrm{v} / \mathrm{v}\right)$. The blue fraction was evaporated, and the resulting solid residue was recrystallized from $\mathrm{CHCl}_{3} /$ hexane to afford free acid $\mathbf{2 a}$ in $90 \%$ yield $(40 \mathrm{mg})$ as a blue solid. Decomposed above $300^{\circ} \mathrm{C}$; IR (KBr) 3400, 3232, 2968, 2933, 1702, 1601, 1458, 1416, 1292, $1094,954,890,839 \mathrm{~cm}^{-1}$; ${ }^{1} \mathrm{H}$ NMR $\left(\mathrm{C}_{5} \mathrm{D}_{5} \mathrm{~N}, 400 \mathrm{MHz}\right) \delta 1.11(\mathrm{t}$, $J=7.5 \mathrm{~Hz}, 3 \mathrm{H}), 2.10(\mathrm{~s}, 3 \mathrm{H}), 2.13(\mathrm{~s}, 3 \mathrm{H}), 2.35(\mathrm{~s}, 3 \mathrm{H}), 2.40(\mathrm{q}$, $J=7.5 \mathrm{~Hz}, 2 \mathrm{H}), 2.83(\mathrm{t}, J=7.1 \mathrm{~Hz}, 2 \mathrm{H}), 2.85-2.90(\mathrm{~m}, 4 \mathrm{H}), 3.14$ (t, $J=7.1 \mathrm{~Hz}, 2 \mathrm{H}), 3.20$ (t, $J=7.1 \mathrm{~Hz}, 2 \mathrm{H}), 4.01(\mathrm{br}, 2 \mathrm{H}), 5.61$ $(\mathrm{dd}, J=11.7,1.2 \mathrm{~Hz}, 1 \mathrm{H}), 5.70(\mathrm{dd}, J=17.8,1.2 \mathrm{~Hz}, 1 \mathrm{H}), 6.31$ (s, 1H), $6.61(\mathrm{~s}, 1 \mathrm{H}), 6.76(\mathrm{dd}, J=17.8,11.5 \mathrm{~Hz}, 1 \mathrm{H}), 7.57$ (s, $1 \mathrm{H}) . \mathrm{NH}$ and $\mathrm{CO}_{2} \underline{\mathrm{H}}$ protons were not observed clearly; UV-vis $(\mathrm{MeOH}) \lambda_{\max } 385(\varepsilon=23355), 645(\varepsilon=17729) \mathrm{nm}$; HRMS (FAB) $\left(\mathrm{M}^{+}+1\right)$, Found: $m / z$ 597.2706. Calcd for $\mathrm{C}_{34} \mathrm{H}_{37} \mathrm{~N}_{4} \mathrm{O}_{6}$ : 597.2713.

3-Oxopropyl Acetate (22). ${ }^{15}$ To a dispersion of $\mathrm{Zn}(\mathrm{OAc})_{2}$. $2 \mathrm{H}_{2} \mathrm{O}(2.2 \mathrm{~g}, 10 \mathrm{mmol})$ in $\mathrm{AcOH}(3.0 \mathrm{~mL}, 50 \mathrm{mmol})$ was added propenal $(5.0 \mathrm{~mL}, 75 \mathrm{mmol})$ dropwise at $40{ }^{\circ} \mathrm{C}$ under $\mathrm{N}_{2}$, and the mixture was allowed to stir for $3 \mathrm{~h}$. After filtration through celite and washing the solid with EtOAc, the filtrate was partitioned between EtOAc and water. Then, the organic layer was washed with a saturated aqueous solution of $\mathrm{NaHCO}_{3}$ and brine, and dried over $\mathrm{Na}_{2} \mathrm{SO}_{4}$. The solvent was evaporated to give compound 22 in $40 \%$ yield ( $2.3 \mathrm{~g}$, a colorless oil), which was used for the next step without further purification. IR (neat) 3062, 2968, 2938, 2853, 2738, 1738, 1650, 1431, 1358, 1367, 1241, 1135, 1050, 956, 864, 793, $733 \mathrm{~cm}^{-1} ;{ }^{1} \mathrm{H} \mathrm{NMR}\left(\mathrm{CDCl}_{3}, 400 \mathrm{MHz}\right) \delta 2.00(\mathrm{~s}, 3 \mathrm{H}), 2.70$ $(\mathrm{dt}, J=6.1,1.5 \mathrm{~Hz}, 2 \mathrm{H}), 4.53(\mathrm{t}, J=6.1 \mathrm{~Hz}, 2 \mathrm{H}), 9.73(\mathrm{t}, J=1.5$ $\mathrm{Hz}, 1 \mathrm{H})$. HRMS (FAB) $\left(\mathrm{M}^{+}+1\right)$, Found: $m / z$ 117.0554. Calcd for $\mathrm{C}_{5} \mathrm{H}_{9} \mathrm{O}_{3}$ : 117.0552 .

3-(2-Acetoxyethyl)-4-ethyl-2-tosylpyrrole (24). To a mixture of compound $22(1.263 \mathrm{~g}, 10.8 \mathrm{mmol})$ and 1-nitropropane $(8.0 \mathrm{~mL}$, $89 \mathrm{mmol})$ was added $0.5 \mathrm{~mL}$ of $1 \mathrm{M} \mathrm{KOH}(0.5 \mathrm{mmol})$ in $\mathrm{MeOH}$ at $0{ }^{\circ} \mathrm{C}$. The reaction mixture was stirred for $2 \mathrm{~h}$ at room temperature. The mixture was quenched with $1 \mathrm{M} \mathrm{HCl}(0.5 \mathrm{~mL})$, and the solvent was evaporated. The residue was partitioned between EtOAc and water, and the organic layer was washed with a saturated aqueous solution of $\mathrm{NaHCO}_{3}$ and then brine, and dried over $\mathrm{Na}_{2} \mathrm{SO}_{4}$. The solvent was evaporated to give the crude nitro-alcohol as an oil. To a mixed solution of the resulting nitro-alcohol (2.09 g, $10.2 \mathrm{mmol})$ and DMAP (124 mg, $1.02 \mathrm{mmol})$ in THF (8.0 $\mathrm{mL})$ was added dropwise acetic anhydride $(1.1 \mathrm{~mL}, 12.2 \mathrm{mmol})$ at $0{ }^{\circ} \mathrm{C}$ under $\mathrm{N}_{2}$. After stirring for $2 \mathrm{~h}$ at room temperature, the mixture was quenched with $\mathrm{MeOH}(1.7 \mathrm{~mL})$, and then, the solvent was removed under reduced pressure. The residue was partitioned between EtOAc and water, and the organic layer was washed with both a saturated aqueous solution of $\mathrm{NaHCO}_{3}$ and brine, and dried over $\mathrm{Na}_{2} \mathrm{SO}_{4}$. The solvent was evaporated to give 4-nitrohexane1,3-diyl diacetate (23) as an oil in $85 \%$ yield (2.28 g) in two steps as a mixture of diastereomers. IR (neat) 2977, 2941, 1746, 1555, $1459,1373,1225,1097,1048,948,809,732 \mathrm{~cm}^{-1}$. HRMS (FAB) $\left(\mathrm{M}^{+}+1\right)$, Found: $m / z$ 248.1140. Calcd for $\mathrm{C}_{10} \mathrm{H}_{18} \mathrm{NO}_{6}: 248.1134$.

To a mixed solution of nitro-diacetate $23(3.64 \mathrm{~g}, 14.7 \mathrm{mmol})$ and TosMIC $(2.866 \mathrm{~g}, 14.7 \mathrm{mmol})$ in $\mathrm{MeCN}(30 \mathrm{~mL})$ under $\mathrm{N}_{2}$, DBU $(4.6 \mathrm{~mL}, 30.9 \mathrm{mmol})$ was added dropwise at $-40^{\circ} \mathrm{C}$, and then, the mixture was allowed to stir for $5 \mathrm{~h}$ at room temperature. The mixture was quenched with aqueous $\mathrm{NH}_{4} \mathrm{Cl}$, and then, the solvent was removed under reduced pressure. The residue was partitioned between EtOAc and water, and the organic layer was successively washed with $6 \mathrm{M} \mathrm{HCl}$, a saturated aqueous solution of $\mathrm{NaHCO}_{3}$ and brine, and dried over $\mathrm{Na}_{2} \mathrm{SO}_{4}$. The solvent was evaporated, and the product $\mathbf{2 4}$ was isolated by flash column chromatography $\left(\mathrm{SiO}_{2}\right.$, hexane/EtOAc $\left.=4 / 1, \mathrm{v} / \mathrm{v}\right)$ as an oil in $59 \%$ yield (2.47 g); IR (neat) 3323, 2965, 2934, 2876, 1738, 1596, $1548,1494,1455,1383,1365,1316,1302,1241,1175,1140$, 1108, 1088, 1067, 1041, 975, 934, 911, 813, 706, $685 \mathrm{~cm}^{-1}$; ${ }^{1} \mathrm{HNMR}\left(\mathrm{CDCl}_{3}, 400 \mathrm{MHz}\right) \delta 1.15(\mathrm{t}, J=7.6 \mathrm{~Hz}, 3 \mathrm{H}), 2.02(\mathrm{~s}$, $3 \mathrm{H}), 2.38(\mathrm{~s}, 3 \mathrm{H}), 2.41(\mathrm{q}, J=7.6 \mathrm{~Hz}, 2 \mathrm{H}), 2.93(\mathrm{t}, J=7.8 \mathrm{~Hz}$, $2 \mathrm{H}), 4.06(\mathrm{t}, J=7.8 \mathrm{~Hz}, 2 \mathrm{H}), 6.74(\mathrm{~d}, J=2.9 \mathrm{~Hz}, 1 \mathrm{H}), 7.27$ (d, $J=8.5 \mathrm{~Hz}, 2 \mathrm{H}), 7.77$ (d, $J=8.5 \mathrm{~Hz}, 2 \mathrm{H}), 9.37$ (brs, 1H). HRMS (FAB) $\left(\mathrm{M}^{+}+1\right)$, Found: $m / z$ 336.1272. Calcd for $\mathrm{C}_{17} \mathrm{H}_{22} \mathrm{NO}_{4} \mathrm{~S}$ : 336.1270 . 
2-Bromo-3-ethyl-4-(2-hydroxyethyl)-5-tosylpyrrole (25). To a solution of the tosylpyrrole $24(2.466 \mathrm{~g}, 7.35 \mathrm{mmol})$ in $\mathrm{CH}_{2} \mathrm{Cl}_{2}$ $(45 \mathrm{~mL})$, a trimethylphenylammonium tribromide $(3.3 \mathrm{~g}, 8.82$ mmol) was added portionwise at $0{ }^{\circ} \mathrm{C}$, and the mixture was allowed to stir for $1 \mathrm{~h}$. The solvent was removed under reduced pressure, and the residue was partitioned between EtOAc and water. The organic layer was washed with a saturated aqueous solution of $\mathrm{NaHSO}_{3}, \mathrm{NaHCO}_{3}$, and brine, and then dried over $\mathrm{Na}_{2} \mathrm{SO}_{4}$. The solvent was evaporated, and the product was separated by flash column chromatography $\left(\mathrm{SiO}_{2}, \mathrm{EtOAc} /\right.$ hexane $\left.=3 / 1, \mathrm{v} / \mathrm{v}\right)$ to give the brominated compound in $85 \%$ yield $(3.71 \mathrm{~g})$ as a solid. Mp $108-109^{\circ} \mathrm{C}$ (from EtOAc/hexane); IR (neat) 3208, 2961, 2929, 2895, 2868, 2360, 1715, 1596, 1547, 1455, 1375, 1321, 1294, 1268, 1207, 1184, 1163, 1139, 1118, 1093, 1065, 1030, 969, 946, 916, 813, 719, 685, $670 \mathrm{~cm}^{-1} ;{ }^{1} \mathrm{HNMR}\left(\mathrm{CDCl}_{3}, 400 \mathrm{MHz}\right) \delta$ $1.07(\mathrm{t}, J=7.6 \mathrm{~Hz}, 3 \mathrm{H}), 2.03(\mathrm{~s}, 3 \mathrm{H}), 2.39(\mathrm{q}, J=7.6 \mathrm{~Hz}, 2 \mathrm{H})$, $2.41(\mathrm{~s}, 3 \mathrm{H}), 2.93(\mathrm{t}, J=7.4 \mathrm{~Hz}, 2 \mathrm{H}), 4.06(\mathrm{t}, J=7.4 \mathrm{~Hz}, 2 \mathrm{H})$, 7.30 (d, $J=8.3 \mathrm{~Hz}, 2 \mathrm{H}), 7.79$ (d, $J=8.3 \mathrm{~Hz}, 2 \mathrm{H}), 9.29$ (brs, $1 \mathrm{H}$ ). Found: C, 49.21; $\mathrm{H}, 4.88 ; \mathrm{N}, 3.38 \%$. Calcd for $\mathrm{C}_{17} \mathrm{H}_{20} \mathrm{BrNO}_{4} \mathrm{~S}$ : C, $49.28 ; \mathrm{H}, 4.87 ; \mathrm{N}, 3.38 \%$. To a solution of the resulting brominated compound $(1.9 \mathrm{~g}, 4.59 \mathrm{mmol})$ in $\mathrm{MeOH}(5 \mathrm{~mL})$ was added $1 \mathrm{M}$ $\mathrm{NaOH}(23 \mathrm{~mL}, 23 \mathrm{mmol})$ dropwise at $0{ }^{\circ} \mathrm{C}$ under $\mathrm{N}_{2}$. After stirring for $1 \mathrm{~h}$ at room temperature, the mixture was neutralized with $1 \mathrm{M}$ $\mathrm{HCl}$, and the solvent was removed under reduced pressure. The organic residue was dissolved in EtOAc and washed with brine and dried over $\mathrm{Na}_{2} \mathrm{SO}_{4}$. The solvent was evaporated, and the residue was separated by flash column chromatography $\left(\mathrm{SiO}_{2}\right.$, hexane/ EtOAc $=3 / 1, \mathrm{v} / \mathrm{v})$ to give compound 25 in $85 \%$ yield $(1.38 \mathrm{~g})$ ( $72 \%$ in two steps) as a solid. Mp $204-205^{\circ} \mathrm{C}$ (from EtOAc/THF/ hexane); IR (KBr) 3451, 3079, 3010, 2966, 2890, 2703, 1735, $1596,1550,1479,1455,1374,1300,1259,1227,1196,1161$, 1135, 1091, 1062, 1036, 1015, 987, 837, 813, 788, 764, 705, 684, $664 \mathrm{~cm}^{-1} ;{ }^{1} \mathrm{H} \mathrm{NMR}\left(\mathrm{CDCl}_{3}, 400 \mathrm{MHz}\right) \delta 1.06(\mathrm{t}, J=7.6 \mathrm{~Hz}, 3 \mathrm{H})$, 1.78 (brs, $1 \mathrm{H}), 2.38(\mathrm{q}, J=7.6 \mathrm{~Hz}, 2 \mathrm{H}), 2.41(\mathrm{~s}, 3 \mathrm{H}), 2.86(\mathrm{t}, J=$ $6.7 \mathrm{~Hz}, 2 \mathrm{H}), 3.72(\mathrm{t}, J=6.7 \mathrm{~Hz}, 2 \mathrm{H}), 7.31(\mathrm{~d}, J=8.4 \mathrm{~Hz}, 2 \mathrm{H})$, 7.78 (d, $J=8.4 \mathrm{~Hz}, 2 \mathrm{H}), 9.17$ (brs, $1 \mathrm{H}$ ). Found: C, 48.47; H, 4.95; N, 3.70\%. Calcd for $\mathrm{C}_{15} \mathrm{H}_{18} \mathrm{BrNO}_{3} \mathrm{~S}: \mathrm{C}, 48.40 ; \mathrm{H}, 4.87 ; \mathrm{N}, 3.76 \%$.

3-Ethyl-4-[2-(mesyloxy)ethyl]-2-oxo-5-tosyl-1,5-dihydro-2Hpyrrole $(9 \mathrm{~b})$. To a solution of the brominated tosylpyrrole 25 $(1.37 \mathrm{~g}, 3.9 \mathrm{mmol})$ in THF $(10 \mathrm{~mL})$ at $0{ }^{\circ} \mathrm{C}, \mathrm{Et}_{3} \mathrm{~N}(1.1 \mathrm{~mL}, 7.8$ mmol) was added under $\mathrm{N}_{2}$, followed by addition of $\mathrm{MeSO}_{2} \mathrm{Cl}$ $(0.36 \mathrm{~g}, 4.7 \mathrm{mmol})$ in THF $(2 \mathrm{~mL})$, and the mixture was allowed to stir at room temperature for $30 \mathrm{~min}$. The solvent was removed under reduced pressure, and the residue was partitioned between EtOAc and water. The organic layer was washed with a saturated aqueous solution of $\mathrm{NaHCO}_{3}$ and with brine, and dried over $\mathrm{Na}_{2} \mathrm{SO}_{4}$. The solvent was evaporated, and the residue was separated by flash column chromatography $\left(\mathrm{SiO}_{2}\right.$, hexane $/$ EtOAc $=3 / 1$, $\mathrm{v} / \mathrm{v})$ to give the mesylated product in $85 \%$ yield $(1.48 \mathrm{~g})$ as a solid, which was used for the next reaction without further purification. IR (KBr) 3276, 3024, 2964, 2940, 2869, 1594, 1550, 1490, 1455, $1382,1343,1319,1292,1256,1204,1169,1138,1119,1092$, 1059, 1014, 980, 948, 859, 817, 782, 770, $714 \mathrm{~cm}^{-1} ;{ }^{1} \mathrm{H} \mathrm{NMR}$ $\left(\mathrm{CDCl}_{3}, 400 \mathrm{MHz}\right) \delta 1.17(\mathrm{t}, J=7.5 \mathrm{~Hz}, 3 \mathrm{H}), 2.39(\mathrm{q}, J=7.5 \mathrm{~Hz}$, $2 \mathrm{H}), 2.42(\mathrm{~s}, 3 \mathrm{H}), 2.95(\mathrm{~s}, 3 \mathrm{H}), 3.04(\mathrm{t}, J=7.5 \mathrm{~Hz}, 2 \mathrm{H}), 4.27(\mathrm{t}$, $J=7.5 \mathrm{~Hz}, 2 \mathrm{H}), 7.32(\mathrm{~d}, J=8.3 \mathrm{~Hz}, 2 \mathrm{H}), 7.78(\mathrm{~d}, J=8.4 \mathrm{~Hz}$, $2 \mathrm{H}), 9.31$ (brs, $1 \mathrm{H})$. The resulting product $(1.03 \mathrm{~g}, 2.3 \mathrm{mmol})$ was dissolved in TFA $(10 \mathrm{~mL})$ at room temperature under $\mathrm{N}_{2}$. After stirring for $15 \mathrm{~min}$, DMSO $(0.65 \mathrm{~mL}, 9.2 \mathrm{mmol})$ was added dropwise, and the mixture was allowed to stir overnight. $\mathrm{Zn}$ $(0.3 \mathrm{~g}, 4.7 \mathrm{mmol})$ was then added portionwise, and the reaction mixture was stirred for $1 \mathrm{~h}$. The TFA was removed under reduced pressure, and the residue was partitioned between EtOAc and water. The organic layer was washed with a saturated aqueous solution of $\mathrm{NaHCO}_{3}$ and with brine, and dried over $\mathrm{Na}_{2} \mathrm{SO}_{4}$. The solvent was evaporated, and the residue was separated by flash column chromatography $\left(\mathrm{SiO}_{2}\right.$, hexane/EtOAc $\left.=2 / 1, \mathrm{v} / \mathrm{v}\right)$ to give compound $9 \mathrm{~b}$ in $65 \%$ yield $(1.03 \mathrm{~g})(55 \%$ in two steps) as a white solid. Mp $140-141{ }^{\circ} \mathrm{C}$ (from EtOAc/hexane); IR (KBr) 3196, 3081, 2969, 1703, 1596, 1460, 1354, 1317, 1259, 1176, 1131, 1080, 990, 975, 906, 830, 721, $668 \mathrm{~cm}^{-1} ;{ }^{1} \mathrm{HNMR}\left(\mathrm{CDCl}_{3}\right.$, $400 \mathrm{MHz}) \delta 0.66(\mathrm{t}, J=7.6 \mathrm{~Hz}, 3 \mathrm{H}), 2.06(\mathrm{dq}, J=14.8,7.6 \mathrm{~Hz}$, $1 \mathrm{H}), 2.11(\mathrm{dq}, J=14.8,7.6 \mathrm{~Hz}, 1 \mathrm{H}), 2.40(\mathrm{~s}, 3 \mathrm{H}), 3.00(\mathrm{~s}, 3 \mathrm{H})$, $3.07(\mathrm{dt}, J=15.4,4.9 \mathrm{~Hz}, 1 \mathrm{H}), 3.11(\mathrm{dt}, J=15.4,4.9 \mathrm{~Hz}, 1 \mathrm{H})$, $4.41(\mathrm{dt}, J=9.8,5.4 \mathrm{~Hz}, 1 \mathrm{H}), 4.51(\mathrm{dt}, J=9.8,4.9 \mathrm{~Hz}, 1 \mathrm{H})$, $5.22(\mathrm{~s}, 1 \mathrm{H}), 6.48$ (brs, $1 \mathrm{H}), 7.30(\mathrm{~d}, J=8.2 \mathrm{~Hz}, 2 \mathrm{H}), 7.64(\mathrm{~d}$, $J=8.2 \mathrm{~Hz}, 2 \mathrm{H})$. Found: C, 49.35; H, 5.50; N, 3.58\%. Calcd for $\mathrm{C}_{16} \mathrm{H}_{21} \mathrm{NO}_{6} \mathrm{~S}_{2}$ : C, 49.60; H, 5.46; N, 3.61\%.

$t$-Butyl (E)-8-(3-Allyloxy-3-oxopropyl)-3-ethyl-9-methyl-2oxo-1,2,4,5-tetrahydrodipyrrolo[1,2-a:2, $\left.2^{\prime} 3^{\prime}-d\right]$ azepine-7-carboxylate (26). To a mixed solution of 5-tosylpyrrolinone $\mathbf{9 b}(25 \mathrm{mg}$, $0.08 \mathrm{mmol})$ and formylpyrrole $\mathbf{1 0 a}(40 \mathrm{mg}, 0.1 \mathrm{mmol})$ in THF $(10 \mathrm{~mL})$, a solution of ${ }^{n} \mathrm{Bu}_{3} \mathrm{P}(32 \mathrm{mg}, 0.16 \mathrm{mmol})$ in THF $(1 \mathrm{~mL})$ was added dropwise at $0{ }^{\circ} \mathrm{C}$ under $\mathrm{N}_{2}$, followed by dropwise addition of DBU $(37 \mathrm{mg}, 0.25 \mathrm{mmol})$ in THF $(2 \mathrm{~mL})$. After stirring overnight at room temperature, the solvent was removed under reduced pressure, and the residue was partitioned between EtOAc and water. The organic layer was washed with both a saturated aqueous solution of $\mathrm{NH}_{4} \mathrm{Cl}$ and brine, and then dried over $\mathrm{Na}_{2} \mathrm{SO}_{4}$. The solvent was evaporated, and the residue was separated by flash column chromatography $\left(\mathrm{SiO}_{2}\right.$, hexane $/ \mathrm{EtOAc}=3 / 1$, $\mathrm{v} / \mathrm{v}$ ) to afford compound $\mathbf{2 6}$ as a yellow solid in $65 \%$ yield (20 mg). Mp $180-181{ }^{\circ} \mathrm{C}$ (from EtOAc/hexane); IR (KBr) 3213, 2973, 2933, 2553, 1736, 1682, 1538, 1481, 1455, 1414, 1396, 1368, 1348, 1284, 1250, 1176, 1129, 1082, 1055, 987, 956, 855, $817,773,735,667 \mathrm{~cm}^{-1} ;{ }^{1} \mathrm{HNMR}\left(\mathrm{CDCl}_{3}, 400 \mathrm{MHz}\right) \delta 1.11(\mathrm{t}$, $J=7.7 \mathrm{~Hz}, 3 \mathrm{H}), 1.58(\mathrm{~s}, 9 \mathrm{H}), 2.06(\mathrm{~s}, 3 \mathrm{H}), 2.38(\mathrm{q}, J=7.1 \mathrm{~Hz}$, $2 \mathrm{H}), 2.52(\mathrm{t}, J=7.9 \mathrm{~Hz}, 2 \mathrm{H}), 2.98(\mathrm{t}, J=8.8 \mathrm{~Hz}, 2 \mathrm{H}), 4.59(\mathrm{~d}$, $J=5.8 \mathrm{~Hz}, 2 \mathrm{H}), 5.26(\mathrm{~d}, J=10.2 \mathrm{~Hz}, 1 \mathrm{H}), 5.30(\mathrm{~d}, J=17.3 \mathrm{~Hz}$, $1 \mathrm{H}), 5.91$ (ddt, $J=17.3,10.2,5.8 \mathrm{~Hz}, 1 \mathrm{H}), 6.28$ (s, 1H), 9.12 (brs, $1 \mathrm{H})$. The protons of the bridged ethylene were not observed clear1y. HRMS (FAB) $\left(\mathrm{M}^{+}+1\right)$, Found: $m / z$ 441.2383. Calcd for $\mathrm{C}_{25} \mathrm{H}_{33} \mathrm{~N}_{2} \mathrm{O}_{5}$ : 441.2389 .

Allyl (E)-3-(3-Ethyl-7-formyl-9-methyl-2-oxo-1,2,4,5-tetra-

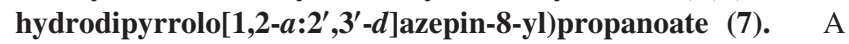
solution of compound $26(20 \mathrm{mg}, 0.043 \mathrm{mmol})$ in TFA $(0.43$ $\mathrm{mL}$ ) was allowed to stir at room temperature under $\mathrm{N}_{2}$ for $30 \mathrm{~min}$. Then, $\left(\mathrm{CH}_{3} \mathrm{O}\right)_{3} \mathrm{CH}(0.22 \mathrm{~mL})$ was added dropwise, and the mixture was allowed to stir at room temperature for $1 \mathrm{~h}$. The reaction mixture was quenched by water and extracted with EtOAc, and then, the organic layer was washed with a saturated aqueous solution of $\mathrm{NaHCO}_{3}$ and with brine, and dried over $\mathrm{Na}_{2} \mathrm{SO}_{4}$. The solvent was evaporated, and the residue was separated by flash column chromatography $\left(\mathrm{SiO}_{2}\right.$, hexane/EtOAc $\left.=3 / 1, \mathrm{v} / \mathrm{v}\right)$ to afford compound 7 as a yellow solid in $85 \%$ yield (16 mg). Mp 175$176^{\circ} \mathrm{C}$ (from EtOAc/hexane). IR (KBr) 3019, 2361, 1728, 1688, 1639, 1502, 1457, 1421, 1381, 1342, 1325, 1302, 1278, 1161, $1050,983,850,734,719,674 \mathrm{~cm}^{-1} ;{ }^{1} \mathrm{HNMR}\left(\mathrm{CDCl}_{3}, 400 \mathrm{MHz}\right)$ $\delta 1.12(\mathrm{t}, J=7.6 \mathrm{~Hz}, 3 \mathrm{H}), 2.08(\mathrm{~s}, 3 \mathrm{H}), 2.39(\mathrm{q}, J=7.6 \mathrm{~Hz}, 2 \mathrm{H})$, $2.57(\mathrm{t}, J=7.7 \mathrm{~Hz}, 2 \mathrm{H}), 2.90(\mathrm{brs}, 2 \mathrm{H}), 3.03(\mathrm{t}, J=7.7 \mathrm{~Hz}, 2 \mathrm{H})$, $4.58(\mathrm{~d}, J=5.9 \mathrm{~Hz}, 2 \mathrm{H}), 5.24(\mathrm{dd}, J=10.5,1.3 \mathrm{~Hz}, 1 \mathrm{H}), 5.29$ $(\mathrm{dd}, J=17.2,1.3 \mathrm{~Hz}, 1 \mathrm{H}), 5.90(\mathrm{ddt}, J=17.2,10.5,5.9 \mathrm{~Hz}, 1 \mathrm{H})$, $6.18(\mathrm{~s}, 1 \mathrm{H}), 8.00(\mathrm{brs}, 1 \mathrm{H}), 9.71(\mathrm{~s}, 1 \mathrm{H})$. The protons of the ethylene bridge were not observed clearly. Found: C, 68.20; H, 6.53; N, 
7.47\%. Calcd for $\mathrm{C}_{21} \mathrm{H}_{24} \mathrm{~N}_{2} \mathrm{O}_{4}$ : C, 68.46; $\mathrm{H}, 6.57 ; \mathrm{N}, 7.60 \%$.

Allyl 3- $\{(Z)-2-(\{(E)-8$-(3-Allyloxy-3-oxopropyl)-3-ethyl-9methyl-2-oxo-1,2,4,5-tetrahydrodipyrrolo[1,2-a:2',3'-d]azepin7-yl\}methylene)-4-methyl-5-[(Z)-(4-methyl-5-oxo-3-vinyl- $1 H$ pyrrol-2(5H)-ylidene)methyl]-2H-pyrrol-3-yl\}propanoate (3b). To a mixed solution of compounds $4(180 \mathrm{mg}, 0.6 \mathrm{mmol})$ and 7 $(110 \mathrm{mg}, 0.3 \mathrm{mmol})$ in $\mathrm{MeOH}(13 \mathrm{~mL})$, a solution of $\mathrm{H}_{2} \mathrm{SO}_{4}(59$ $\mathrm{mg}, 0.6 \mathrm{mmol})$ in $\mathrm{MeOH}(2 \mathrm{~mL})$ was added dropwise at room temperature under $\mathrm{N}_{2}$. After stirring for $1 \mathrm{~h}$, the reaction mixture was quenched by a buffer solution (pH 7.0) and extracted by EtOAc. The organic layer was washed with brine and dried over $\mathrm{Na}_{2} \mathrm{SO}_{4}$. The solvent was evaporated, and the blue residue was separated by thin layer chromatography (hexane $/ \mathrm{CHCl}_{3} / \mathrm{MeOH}=7 / 4 / 0.5$, $\mathrm{v} / \mathrm{v} / \mathrm{v}$ ) to give compound $\mathbf{3 b}$ as a greenish blue solid in $45 \%$ yield (20 mg). Decomposed above $200^{\circ} \mathrm{C}$ (from EtOAc/hexane). IR (KBr) 3224, 2933, 1734, 1698, 1676, 1584, 1508, 1419, 1348, 1272, 1227, 1158, 984, 958, 669 $\mathrm{cm}^{-1} ;{ }^{1} \mathrm{HNMR}\left(\mathrm{CDCl}_{3}, 400\right.$ MHz) $\delta 1.07(\mathrm{t}, J=7.6 \mathrm{~Hz}, 3 \mathrm{H}), 2.06(\mathrm{~s}, 3 \mathrm{H}), 2.10(\mathrm{~s}, 3 \mathrm{H}), 2.13$ $(\mathrm{s}, 3 \mathrm{H}), 2.36(\mathrm{q}, J=7.3 \mathrm{~Hz}, 2 \mathrm{H}), 2.52(\mathrm{t}, J=7.8 \mathrm{~Hz}, 2 \mathrm{H}), 2.59(\mathrm{t}$, $J=7.8 \mathrm{~Hz}, 2 \mathrm{H}), 2.97(\mathrm{t}, J=7.8 \mathrm{~Hz}, 2 \mathrm{H}), 2.98(\mathrm{t}, J=7.8 \mathrm{~Hz}$, $2 \mathrm{H}), 3.12(\mathrm{~m}, 2 \mathrm{H}), 4.52(\mathrm{~d}, J=5.6 \mathrm{~Hz}, 2 \mathrm{H}), 4.56(\mathrm{~d}, J=5.6 \mathrm{~Hz}$, $2 \mathrm{H}), 5.18-5.30(\mathrm{~m}, 4 \mathrm{H}), 5.68(\mathrm{~d}, J=11.7 \mathrm{~Hz}, 1 \mathrm{H}), 5.71(\mathrm{~d}, J=$ $17.0 \mathrm{~Hz}, 1 \mathrm{H}), 5.78-5.94(\mathrm{~m}, 1 \mathrm{H}), 6.07(\mathrm{~s}, 1 \mathrm{H}), 6.16(\mathrm{~s}, 1 \mathrm{H}), 6.54$ $(\mathrm{dd}, J=18.0,11.7 \mathrm{~Hz}, 1 \mathrm{H}), 6.92(\mathrm{~s}, 1 \mathrm{H}), 7.14(\mathrm{~s}, 1 \mathrm{H})$. One $\mathrm{NH}$ and bridged ethylene protons were not appeared clearly. HRMS (FAB) $\left(\mathrm{M}^{+}+1\right)$, Found: $m / z$ 677.3334. Calcd for $\mathrm{C}_{40} \mathrm{H}_{45} \mathrm{~N}_{4} \mathrm{O}_{6}$ : 677.3339 .

3-\{(Z)-2-(\{(E)-8-(3-Carboxyethyl)-3-ethyl-9-methyl-2-oxo$1,2,4,5$-tetrahydrodipyrrolo $\left[1,2-a: 2^{\prime}, 3^{\prime}-d\right]$ azepin-7-yl $\}$ methylene)-4-methyl-5-[(Z)-(4-methyl-5-oxo-3-vinyl-1H-pyrrol-2(5H)ylidene)methyl]-2H-pyrrol-3-yl\}propanoic acid (3a). To a mixed solution of compound $\mathbf{3 b}(20 \mathrm{mg}, 0.03 \mathrm{mmol})$ and $[\mathrm{Pd}-$ $\left.\left(\mathrm{PPh}_{3}\right)_{4}\right](7 \mathrm{mg}, 0.006 \mathrm{mmol})$ in THF $(1.3 \mathrm{~mL})$, a solution of NaTs $(11 \mathrm{mg}, 0.06 \mathrm{mmol})$ in $\mathrm{MeOH}(1.3 \mathrm{~mL})$ was added at room temperature under $\mathrm{N}_{2}$. After stirring for $10 \mathrm{~min}$, the solvent was evaporated, and the residue was separated by flash column chromatography $\left(\mathrm{SiO}_{2}, \mathrm{CHCl}_{3} / \mathrm{MeOH} / \mathrm{AcOH}=200 / 15 / 1, \mathrm{v} / \mathrm{v} / \mathrm{v}\right)$. The greenish blue fraction was concentrated, and the resulting solid was recrystallized from $\mathrm{CHCl}_{3} /$ hexane to afford free acid $\mathbf{3 a}$ in $42 \%$ yield $(7 \mathrm{mg})$ as a greenish blue solid. Decomposed above $250^{\circ} \mathrm{C}$; IR (KBr) 3418, 2934, 1732, 1697, 1585, 1435, 1272, $1158,1101,959,692 \mathrm{~cm}^{-1} ;{ }^{1} \mathrm{HNMR}\left(\mathrm{C}_{5} \mathrm{D}_{5} \mathrm{~N}, 400 \mathrm{MHz}\right) \delta 1.11$ $(\mathrm{t}, J=7.3 \mathrm{~Hz}, 3 \mathrm{H}), 2.06(\mathrm{~s}, 6 \mathrm{H}), 2.19(\mathrm{~s}, 3 \mathrm{H}), 2.67$ (q, $J=7.6 \mathrm{~Hz}$, $2 \mathrm{H}), 2.88(\mathrm{t}, J=7.6 \mathrm{~Hz}, 2 \mathrm{H}), 2.97(\mathrm{t}, J=7.6 \mathrm{~Hz}, 2 \mathrm{H}), 3.32(\mathrm{t}$, $J=7.3 \mathrm{~Hz}, 4 \mathrm{H}), 3.43(\mathrm{br}, 2 \mathrm{H}), 5.60(\mathrm{~d}, J=11.5 \mathrm{~Hz}, 1 \mathrm{H}), 5.73(\mathrm{~d}$, $J=17.8 \mathrm{~Hz}, 1 \mathrm{H}), 6.36(\mathrm{~s}, 1 \mathrm{H}), 6.38(\mathrm{~s}, 1 \mathrm{H}), 6.78(\mathrm{dd}, J=18.0$, $11.2 \mathrm{~Hz}, 1 \mathrm{H}), 7.62(\mathrm{~s}, 1 \mathrm{H}), 11.14(\mathrm{br}, 1 \mathrm{H})$. Protons of $\mathrm{CO}_{2} \underline{\mathrm{H}}$, one $\mathrm{N} \underline{\mathrm{H}}$, and bridged ethylene were not appeared clearly. UVvis $(\mathrm{MeOH}) \lambda_{\max } 388(\varepsilon=28675), 648(\varepsilon=13100) \mathrm{nm}$; HRMS (FAB) $\left(\mathrm{M}^{+}+1\right)$, Found: $m / z$ 597.2718. Calcd for $\mathrm{C}_{34} \mathrm{H}_{37} \mathrm{~N}_{4} \mathrm{O}_{6}$ : 597.2713.

The present work was financially supported in part by Grant-in-Aid for Scientific Research (B) (No. 15350021) from Japan Society for the Promotion of Science (JSPS).

\section{References}

1 a) M. Ahmad, A. R. Cashmore, Nature 1993, 366, 162; A. Sancar, Chem. Rev. 2003, 103, 2203; D. Shalitin, X. Yu, M. Maymon, T. Mockler, C. Lin, Plant Cell 2003, 15, 2421. b) E. Huala, P. W. Oeller, E. Liscum, I. S. Han, E. Larsen, W. R.
Briggs, Science 1997, 278, 2120; J. M. Christie, P. Reymond, G. K. Powell, P. Bernasconi, A. A. Raibekas, E. Liscum, W. R. Briggs, Science 1998, 282, 1698; W. R. Briggs, J. M. Christie, Trends Plant Sci. 2002, 7, 204; S. M. Harper, L. C. Neil, K. H. Gardner, Science 2003, 301, 1541; R. Fedorov, I. Schlichting, E. Hartmann, T. Domratcheva, M. Fuhrmann, P. Hegemann, Biophys. J. 2003, 84, 2474. c) W. Rüdiger, F. Thümmler, Photomorphogenesis of Plants, 2nd ed., ed. by R. E. Kendrick, G. H. M. Kronenberg, Kluwer Academic Publishers, Dordrecht, The Netherlands, 1994; C. R. Nathan, S. Yi-Shin, J. C. Lagarias, Annu. Rev. Plant Biol. 2006, 57, 837.

2 M. A. Mroginski, D. H. Murgida, D. von Stetten, C. Kneip, F. Mark, P. Hildebrandt, J. Am. Chem. Soc. 2004, 126, 16734.

3 T. Lamparter, N. Michael, O. Caspani, T. Miyata, K. Shirai, K. Inomata, J. Biol. Chem. 2003, 278, 33786.

4 H. Falk, The Chemistry of Linear Oligopyrroles and Bile Pigments, Springer Verlag, Wien, New York, 1989.

5 F. Andel, III, J. T. Murphy, J. A. Haas, M. T. McDowell, I. van der Hoef, J. Lugtenburg, J. C. Lagarias, R. A. Mathies, Biochemistry 2000, 39, 2667.

6 Y. Mizutani, S. Tokutomi, T. Kitagawa, Biochemistry 1994, 33, 153 .

7 C. Kneip, P. Hildebrandt, W. Schlamann, S. E. Braslavsky, F. Mark, K. Schaffner, Biochemistry 1999, 38, 15185.

8 a) H. Kinoshita, Y. Hayashi, Y. Murata, K. Inomata, Chem. Lett. 1993, 1437. b) H. Kinoshita, H. Ngwe, K. Kobori, K. Inomata, Chem. Lett. 1993, 1441. c) K. Kohori, M. Hashimoto, H. Kinoshita, K. Inomata, Bull. Chem. Soc. Jpn. 1994, 67, 3088. d) T. Kakiuchi, H. Kato, K. P. Jayasundera, T. Higashi, K. Watabe, D. Sawamoto, H. Kinoshita, K. Inomata, Chem. Lett. 1998, 1001. e) K. P. Jayasundera, H. Kinoshita, K. Inomata, Chem. Lett. 1998, 1227. f) T. Kakiuchi, H. Kinoshita, K. Inomata, Synlett 1999, 901. g) A. Ohta, D. Sawamoto, K. P. Jayasundera, H. Kinoshita, K. Inomata, Chem. Lett. 2000, 492. h) D. Sawamoto, H. Nakamura, H. Kinoshita, S. Fujinami, K. Inomata, Chem. Lett. 2000, 1398. See also the references cited therein. i) S. Takeda, K. P. Jayasundera, T. Kakiuchi, H. Kinoshita, K. Inomata, Chem. Lett. 2001, 590.

9 H. Hanzawa, K. Inomata, H. Kinoshita, T. Kakiuchi, K. P. Jayasundera, D. Sawamoto, A. Ohta, K. Uchida, K. Wada, M. Furuya, Proc. Natl. Acad. Sci. U.S.A. 2001, 98, 3612; A related paper was reported: U. Robben, I. Lindner, W. Gärtner, K. Schaffner, Angew. Chem., Int. Ed. 2001, 40, 1048.

10 a) H. Hanzawa, T. Shinomura, K. Inomata, T. Kakiuchi, H. Kinoshita, K. Wada, M. Furuya, Proc. Natl. Acad. Sci. U.S.A. 2002, 99, 4725. b) K. Inomata, Chem. Today 2004, No. 398, 56.

11 M. A. S. Hammam, Y. Murata, H. Kinoshita, K. Inomata, Chem. Lett. 2004, 33, 1258.

12 The synthesis of BV derivative locked in E-anti configuration and conformation has been reported as a short communication. See Ref. 17.

13 a) P. Manitto, D. Monti, J. Chem. Soc., Chem. Commun. 1980, 178. b) I. Lindner, B. Knipp, S. E. Braslavslky, W. Gärtner, K. Schaffner, Angew. Chem., Int. Ed. 1988, 37, 1843. c) D. Sawamoto, K. Inomata, Chem. Lett. 2001, 588.

14 D. H. R. Barton, J. Kervogoret, S. Z. Zard, Tetrahedron 1990, 46, 7587.

15 R. Tsumura, M. Kanemaru, N. Ishii, Japan Kokai Tokkyo Koho 7505315, 1975; Chem. Abstr. 1975, 83, 27573q; T. Urasaki, W. Funakoshi, Japan Kokai Tokkyo Koho 76131817, 1976; Chem. Abstr. 1977, 86, 120786h. 
16 K. Inomata, M. A. S. Hammam, H. Kinoshita, Y. Murata, H. Khawn, S. Noack, N. Michael, T. Lamparter, J. Biol. Chem. 2005, 280, 24491.
17 H. Kinoshita, M. A. S. Hammam, K. Inomata, Chem. Lett. 2005, 34, 800 . 